\title{
Amine- and Amino Acid-Based Compounds as Carbonic Anhydrase Activators
}

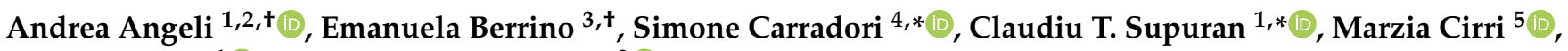 \\ Fabrizio Carta ${ }^{1}$ and Gabriele Costantino ${ }^{2}$ (D) \\ 1 NEUROFARBA Department, Pharmaceutical and Nutraceutical Section, University of Florence, via Ugo \\ Schiff 6, 50019 Sesto Fiorentino, FI, Italy; andrea.angeli@unifi.it (A.A.); fabrizio.carta@unifi.it (F.C.) \\ 2 Department of Food and Drug, University of Parma, Parco Area delle Scienze, 27/A, 43124 Parma, Italy; \\ gabriele.costantino@unipr.it \\ 3 Department of Drug Chemistry and Technologies, Sapienza University of Rome, P.le A. Moro 5, \\ 00185 Rome, Italy; emanuela.berrino@uniroma1.it \\ 4 Department of Pharmacy, "G. d'Annunzio" University of Chieti-Pescara, via dei Vestini 31, 66100 Chieti, Italy \\ 5 Department of Chemistry, University of Florence, via Ugo Schiff 6, 50019 Sesto Fiorentino, FI, Italy; \\ marzia.cirri@unifi.it \\ * Correspondence: simone.carradori@unich.it (S.C.); claudiu.supuran@unifi.it (C.T.S.) \\ + These authors contributed equally to this work.
}

check for updates

Citation: Angeli, A.; Berrino, E.; Carradori, S.; Supuran, C.T.; Cirri, M.; Carta, F.; Costantino, G. Amine- and Amino Acid-Based Compounds as Carbonic Anhydrase Activators. Molecules 2021, 26, 7331. https:// doi.org/10.3390/molecules26237331

Academic Editor: Cesar Mateo

Received: 27 October 2021

Accepted: 1 December 2021

Published: 2 December 2021

Publisher's Note: MDPI stays neutral with regard to jurisdictional claims in published maps and institutional affiliations.

Copyright: (c) 2021 by the authors. Licensee MDPI, Basel, Switzerland. This article is an open access article distributed under the terms and conditions of the Creative Commons Attribution (CC BY) license (https:// creativecommons.org/licenses/by/ $4.0 /)$.

\begin{abstract}
After being rather neglected as a research field in the past, carbonic anhydrase activators (CAAs) were undoubtedly demonstrated to be useful in diverse pharmaceutical and industrial applications. They also improved the knowledge of the requirements to selectively interact with a CA isoform over the others and confirmed the catalytic mechanism of this class of compounds. Amino acid and amine derivatives were the most explored in in vitro, in vivo and crystallographic studies as CAAs. Most of them were able to activate human or non-human CA isoforms in the nanomolar range, being proposed as therapeutic and industrial tools. Some isoforms are better activated by amino acids than amines derivatives and the stereochemistry may exert a role. Finally, non-human CAs have been very recently tested for activation studies, paving the way to innovative industrial and environmental applications.
\end{abstract}

Keywords: carbonic anhydrase; activators; amino acid; amine; isoform selectivity; coral; protozoa; fungi; learning and cognitive impairment; neurodegenerative diseases

\section{Introduction}

\subsection{Amino Acids and Biogenic Amines}

Amino acids (AAs) do possess significant roles in Medicinal Chemistry either as free drugs or being constitutive elements within more complex structures in natural products or within synthetic compounds [1-3]. The main advantage in dealing with amino acids is to acquire readily available building blocks bearing features such as: (i) orthogonal protecting groups conveniently adjustable by means of well-established synthetic methods (i.e., acylation, alkylation among others); (ii) additional moieties usable to meet the synthetic needs and (iii) chiral centers, with major optical differences between the series produced by eukaryotic or prokaryotic organisms. More importantly all such features are packed into low molecular weight compounds with beneficial effects on their handling and treatment. Among the 22 "proteinogenic" amino acids are included those coded and noncoded, the ones obtained from post-translational modifications [1]. The non-proteinogenic amino acids are not included in protein's primary sequences and they usually are produced as metabolites from bacteria, fungi, plants or marine organisms. In consideration of the unique structural as well as biological features of many non-naturally occurring amino acids, great efforts have been devoted to the development of appropriate synthetic protocols with the aim to readily obtain innovative building blocks $[1,2,4]$. 
Decarboxylation of amino acids, amination or transamination of aldehydes and / or ketones are the main transformations which afford Biogenic Amines (BAs) as naturally occurring organic compounds. BAs are largely present in all organisms and are endowed with variegate physio/pathological features which make them of particular interest within the Medicinal Chemistry field [5].

The purpose of this work is to offer an up-to-date comprehensive overview on AAs, BAs and their synthetic analogues which act in vitro as activators of the metalloenzymes Carbonic Anhydrases (CAs; EC 4.2.1.1) considering this topic is acquiring increased attention among the scientific community for biomedical as well as technological applications.

\subsection{CA Families}

The reversible hydration of carbon dioxide is a minimal transformation which assumes paramount importance within our world of carbon-based life, operating in a water-based medium. All forms of life on Earth share the same biochemistry, which relies on the infinite number of chemical transformations on the "carbon" element. The conversion of carbon into its biologically fruitful form, as well as its detraction, is chemically represented in Equation (1):

$$
\mathrm{CO}_{2}+\mathrm{H}_{2} \mathrm{O} \leftrightarrow \mathrm{HCO}_{3}{ }^{-}+\mathrm{H}^{+}
$$

At the intracellular concentrations of $\mathrm{CO}_{2}$, the uncatalyzed $\mathrm{k}_{\text {cat }}$ values for the hydration and dehydration steps are of $0.15 \mathrm{~s}^{-1}$ and $50 \mathrm{~s}^{-1}$, respectively, and thus significantly below the threshold for the biochemical transformations in maintaining the evolution of life [6]. In this context are the Carbonic Anhydrase (CA; EC 4.2.1.1) enzymes which are particularly efficient in speeding-up this equilibrium, thus allowing it in covering any biological need. The abundance of genetic families (i.e., eight and non-correlated to each other) and the multitude of isoforms expressed within some of them clearly reflects the remarkable physio/pathological value of such enzymes which are among the most striking examples of convergent evolution in biology [6,7]. According to the genetic branch, CAs are identified as $\alpha-, \beta-, \gamma-, \delta_{-}, \zeta_{-}, \eta-, \theta-$, and $\mathrm{t}$-classes. The first class is the most investigated and comprises isozymes expressed into vertebrates (also including the 15 isoforms reported in humans) algae, coral, protozoa, filamentous ascomycetes and bacterial strains. The main differences occurring between the various $\alpha$-subclasses are mainly related to secondary and tertiary organization of the apoprotein which in turn determines specific physical/chemical features such as compactness, thermal, chemical and physical stability. On the other hand, the catalytic core is conserved among all the $\alpha$-family and it consists of a $\mathrm{Zn}$ (II) ion tetrahedrally coordinated by three histidine residues and a $\mathrm{H}_{2} \mathrm{O} / \mathrm{OH}^{-}$ molecule [8].

The $\beta$-CAs catalytic cluster consists of two cysteines and a histidine residue that coordinate the metal ion (i.e., $\mathrm{Zn}$ or $\mathrm{Co}$ ) along with an aspartate and arginine dyad which form a $\mathrm{pH}$ dependent gate responsible in switching the enzyme between the catalytically active and inactive forms. Monomeric $\beta$-CAs present peculiar $\alpha / \beta$ folding clusters which can be distinguished in subclasses of the plant- and cab-type. In addition, the monomeric units are organized to afford functionally active quaternary structures up to octamers. The distribution of the $\beta$-CAs is quite large in plants, yeasts, bacteria, fungi, and invertebrates, whereas is completely missing in vertebrates [9]. Extensive structural and kinetic investigations on both $\alpha$ - and $\beta$-CAs allowed to decipher the mechanistic features proper of the two classes. Important differences are on the release of the proton produced from each single catalytic cycle which also determines its rate. Among the $\alpha$-family a histidine residue (i.e., His64 according to the human CA II numbering) flips between two opposite conformations called "in" and "out" thus expelling the catalytically generated protons in the enzyme outer space by means of the hydrophilic cavity section $[6,10]$. As for the $\beta$-CAs the mechanisms regulating the extrusion of protons is not completely understood despite a large number of experiments were conducted [11].

The $\gamma$-class is widely distributed among the Bacteria and Archaea domains, whereas in eukaryotes have been described only in organisms endowed with photosynthetic abilities. 
Among this class the CA from Methanosarcina thermophila (Cam) still remains the best characterized isoform within this family [12]. X-ray crystallographic experiments clearly showed the active enzyme organized as a homotrimer resulting from the packing of three left-handed $\beta$-helices and the catalytic core being placed at the interface between each adjacent monomer [13]. The catalytic core accounts for a metal (II) ion (i.e., Fe, Zn or Co) coordinated according to a trigonal bipyramidal geometry by means of a $\mathrm{H}_{2} \mathrm{O} / \mathrm{OH}^{-}$ molecule and two histidine residues from a monomer and one histidine from the adjacent monomer. Although not deciphered in detail, the mechanism for the $\gamma$-class is assumed to proceed in analogy to the $\alpha$-class [14].

As for the $\delta$-family no structural data are currently available and the only relevant information is on the catalytic core which resembles to the cluster in $\alpha$ - and $\gamma$-CAs (i.e., three histidine residues coordinating the metal ion). Of note is the metal promiscuity of the $\delta$-class which may be both $\mathrm{Zn}$ (II) or $\mathrm{Co}$ (II) with no particular effects on the kinetics. The distribution of the $\delta$-CAs appears exclusive in marine diatoms and therefore plays a pivotal role in the $\mathrm{CO}_{2}$ sequestration process from the atmosphere at global scale [15]. Genetic analysis of the marine diatom Thalassiosira weissflogii revealed sequences encoding for a $\zeta$-CA also named CDCA1. Such an enzyme was also found expressed in T. pseudonana diatoms and similar genes were also identified in other diatom species [16,17]. CDCA1 is properly referred as a cambialistic enzyme due to its capability to naturally incorporate either a Cd(II) or a $\mathrm{Zn}$ (II) ion at its metal center within a coordination cluster formed of two Cys and one His residues. Despite the metal switch marginally influences the enzymatic performances, which is close to the limit of diffusion [18], studies revealed important differences when in vitro kinetic studies were performed being the Cd-CDCA1 completely insensitive to activation compared with the Zn-CDCA1 enzyme [19]. $\eta$-CAs represent a quite interesting family as to date has been isolated only in Plasmodium spp. and it seems involved in the biosynthesis of pyrimidine scaffolds by providing $\mathrm{HCO}_{3}{ }^{-}$as source of carbon units $[20,21]$. The catalytic core within the $\eta$-class is constituted by two histidine and one glutamine residues able to coordinate the $\mathrm{Zn}(\mathrm{II})$ ion according to the classical tetrahedral geometry [22,23]. Despite the high sequence homology between the $\eta$ - and $\alpha$-classes, crystallographic studies showed that no metal ion is present and in vitro inhibition experiments confirmed that the enzymatic activity was not affected by classical inhibitors [24]. All such data clearly indicated $\eta$-class to possess a distinctive mechanism when compared to other CA-families and yet to be defined.

The $\beta$-class was firstly reported in 2016 from the diatom Phaeodactylum tricornutum (PtCA1) [25]. Structural and biochemical data indicated such a class to possess many structural features proper of the $\beta$-family isozymes (i.e., the catalytic cluster and specific structural domains), but it is endowed with esterase activity which is exclusive of the $\alpha$-class.

The last CA family that was very recently identified is referred as t-. Such a CA was firstly isolated from the diatom Thalassiosira pseudonana and subsequently found in algae, bacteria, and archaea [26-28]. From the structural view point the t-class is unique since primary structure alignments with all CAs known to date do not show any of the amino acid residues necessary for the metal ion to be coordinated. Such an observation was particularly puzzling considering the elevated kinetic parameters for the hydration rection (i.e., $\mathrm{t}$-CA from Burkholderia territorii: $\mathrm{k}_{\mathrm{cat}}$ of $3.0 \times 10^{5} \mathrm{~s}^{-1}$ and $\mathrm{k}_{\mathrm{cat}} / \mathrm{K}_{\mathrm{M}}$ of $3.9 \times 10^{7} \mathrm{M}^{-1} \mathrm{~s}^{-1}$ ) and the catalytic activity observed when $\mathrm{Zn}^{2+}$ (or $\mathrm{Mn}^{2+}$ for $\mathrm{l}-\mathrm{CA}$ from diatoms) was added to the culture media for enzyme expression [27]. More recently, Hirakawa et al. identified two novel CAs encoded by an eukaryotic microalga and a cyanobacterium (indicated as BnaCA and AspCA, respectively), showing the same consensus sequence typical of ı-CAs [29]. However, the enzymes were found to be catalytically active without the metal ion, and a putative catalytic mechanism was proposed, with the hydroxyl groups of amino acidic residues (i.e., Thr106, Tyr124 and Ser199) involved in the deprotonation of the active site water [29]. It is unclear whether these metal-free CAs belong to a ı-CA subclass or 
whether all ı-CAs discovered so far do not need a metal cofactor for the catalytic cycle and the zinc or manganese ion required for the activity only has a structural function [7].

\subsection{Carbonic Anhydrase Activators (CAAs)}

The innovative class of CA activators (CAAs) is increasingly gaining consideration within the biomedical and technological fields. Traditionally the approach to further enhance kinetic performances of such enzymes, which are among the most efficient known so far, has been discarded or just received modest attention mainly as CA inhibitors (CAIs) are endowed with immediate applicability and thus resulting in higher appealing. The activation of CAs was independently reported by several research groups working on biogenic amines such as the histamine, amino acids and small peptides [30-33]. However, no particular efforts were made with the intent to decipher the CAAs enzymatic mechanism until the early ' 90 , when the general model of action in Equation (2) has been proposed [34] (E: enzyme; A: activator).

$$
\begin{gathered}
\mathrm{EZn}^{2+}-\mathrm{OH}_{2}+\mathrm{A} \leftrightarrow\left[\mathrm{EZn}^{2+}-\mathrm{OH}_{2}-\mathrm{A}\right] \leftrightarrow \\
{\left[\mathrm{EZn}^{2+}-\mathrm{HO}^{-}-\mathrm{AH}^{+}\right] \leftrightarrow \mathrm{EZn}^{2+}-\mathrm{HO}^{-}+\mathrm{AH}^{+}} \\
\text {Enzyme-activator complexes }
\end{gathered}
$$

Such a model stands on the generation of an enzyme-activator complex, which takes part to the rate-determining step of the catalytic cycle. Since the complex is of intramolecular nature, it necessarily means that the proton transfer process is expected to be far more efficient when compared to the same happening via an intermolecular fashion [34-36]. The proposed model was also well suited to the pioneering study reported by Tu et al. on the imidazole tail of His64 (assuming the hCA II as model for the $\alpha$-class) acting as proton shuttle (pKa 7) for the regeneration of the enzymatically active CA species [36]. Among the variegate contributions in support of the proposed mechanism, the most striking ones are represented by the X-ray crystal structures of the hCA II-activator adducts [37,38]. In particular, histamine 12, the first activator to be crystalized within CA, was found to bind far from the metal ion, in a region also occupied by His64, participating to the complex water network between the zinc ion and the proton-shuttling residue, thus accelerating the regeneration of the enzyme active form. This region, called activator-binding site A, was found to be occupied also by the other activators subsequently crystallized within CA II (Figure 1) [39-41], with the only exception represented by D-Trp. This amino acid binds in a distinct region of the active site, called activator-binding site $\mathrm{B}$, although the molecular portions responsible of the proton-shuttling activity (amino and carboxylic groups) are located close to the site A (Figure 1) [42]. Petreni et al. recently performed a very detailed structural analysis of CAAs binding mode, looking at the crystallographic data currently available for the hCA isoform II in adduct with amines and amino acids [43]. In particular, the study aimed to compare the binding mode of CAAs with the one showed by hydrolyzed coumarins, belonging to a non-classic CA inhibitor family. Coumarins, hydrolyzed by the CA esterase activity to 2-hydroxycinnamic acids, occlude the active site entrance and are known to bind in the same region of the enzyme active site occupied by CAAs $[44,45]$. Both coumarins and CAAs were shown to interact with superimposable amino acid residues, with many water molecules participating to the stabilization of the modulator/enzyme adduct. This phenomenon, unique among all enzymes, highlights the crucial role of specific structural features to be inserted within a CA modulator in the drug design process in order to address the desired biological effect. 


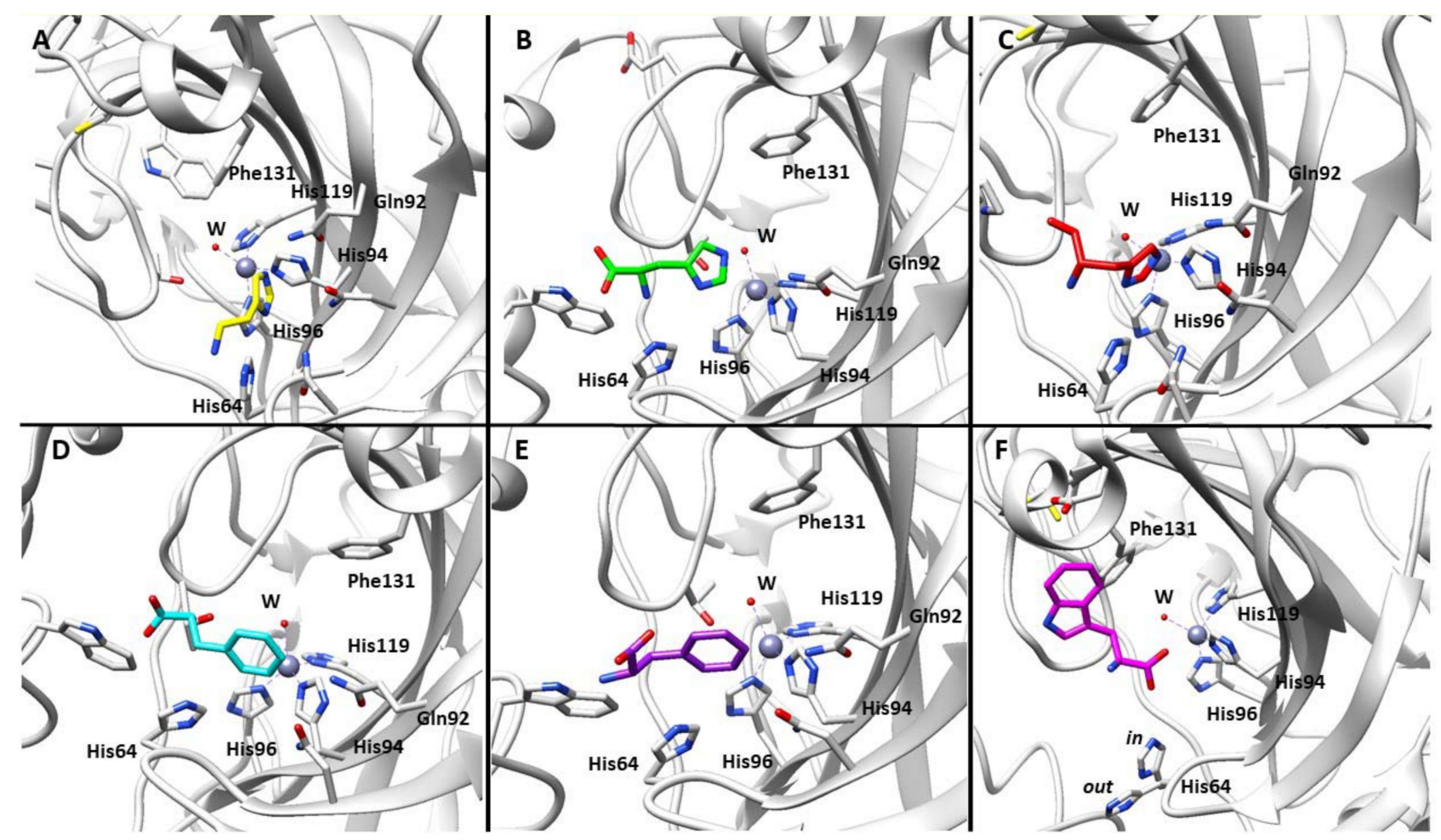

Figure 1. Cartoon views of hCA II/activator complexes as determined by X-ray crystallography. The activators are (A) histamine 12 in yellow (PDB 1AVN) [37]; (B) D-His 2 in green (PDB 2EZ7) [39]; (C) L-His 1 in red (PDB 2ABE) [39]; (D) D-Phe 4 in cyan (PDB 2FMZ); (E) L-Phe 3 in purple (PDB 2FMG) [42]; and (F) D-Trp 6 in magenta (PDB 3EFI) [42].

In particular, a CAA has to be a small molecule fitting into the active site and possessing chemical moieties able to participate to the proton-shuttling process (Figure 2). Such characteristics referred to specific examples will be properly discussed later, because small structural differences may impact a lot on this biological behavior.

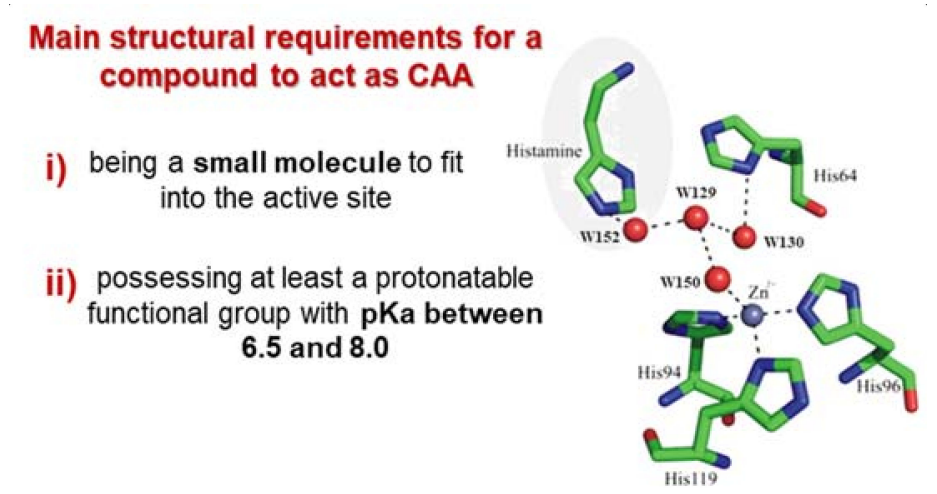

Figure 2. Histamine in complex with hCA II. Hydrogen bonding pathways linking the zinc-bound water molecule, Wat150, to the histamine molecule and to His64 [37].

\section{Activation Assay}

The in vitro assessment of the CA-activation properties of compounds of interest is properly obtained by measuring the $\mathrm{CO}_{2}$ hydration reaction rate means of the stop-flow instrument technique, performed on the method firstly reported by Khalifah [46,47].

The methodology used to perform such an assay relies on monitoring the $\mathrm{CO}_{2}$ hydration in Equation (1) within a reaction chamber at a wavelength of $557 \mathrm{~nm}$ for a timeframe fixed up to $10 \mathrm{~s}$ by using a proper $\mathrm{pH}$ indicator (i.e., usually Phenol red). Saturated solutions of the $\mathrm{CA}$ substrate (i.e., $\mathrm{CO}_{2}$ ) in $\mathrm{H}_{2} \mathrm{O}$ at $25^{\circ} \mathrm{C}$ as well as stock solutions containing 
the potential CAAs, the enzyme and the indicator are prepared separately using the same aqueous buffer. Usually, CAAs and the recombinant enzyme solutions are preincubated for $15 \mathrm{~min}$ at room temperature prior the assay, in order to allow for the formation of the enzyme-activator complex as reported in Equation (1). The activation constant $\left(\mathrm{K}_{\mathrm{A}}\right)$ can be obtained by considering the classical Michaelis-Menten equation which has been fitted by non-linear least squares by using PRISM 3 and below reported:

$$
\mathrm{V}=\mathrm{V}_{\max } /\left\{1+\mathrm{K}_{\mathrm{M}} /[\mathrm{S}]\left(1+[\mathrm{A}]_{\mathrm{f}} / \mathrm{K}_{\mathrm{A}}\right\}\right.
$$

The term [A] refers to the free concentration of the CAA.

Assuming that at the operative experimental conditions the concentration of substrate is lower than $\mathrm{K}_{\mathrm{M}}$ and that $[\mathrm{A}]_{\mathrm{f}}$ can be represented in the form of the total concentration of the enzyme $\left([\mathrm{E}]_{\mathrm{t}}\right)$ and activator $\left([\mathrm{A}]_{\mathrm{t}}\right)$, the obtained competitive steady-state equation for determining $\mathrm{K}_{\mathrm{A}}$ is:

$$
\left.\mathrm{V}=\mathrm{V}_{\mathrm{o}} \mathrm{K}_{\mathrm{A}} /\left\{\mathrm{K}_{\mathrm{A}}+[\mathrm{A}]_{\mathrm{t}}-0.5\left\{\left([\mathrm{~A}]_{\mathrm{t}}+[\mathrm{E}]_{\mathrm{t}}+\mathrm{K}_{\mathrm{A}}\right)-\left([\mathrm{A}]_{\mathrm{t}}+[\mathrm{E}]_{\mathrm{t}}+\mathrm{K}_{\mathrm{A}}\right)^{2}-4[\mathrm{~A}]_{\mathrm{t}}[\mathrm{E}]_{\mathrm{t}}\right)^{1 / 2}\right\}\right\}
$$

In the equation above, the term $V_{0}$ represents the initial velocity of the enzymecatalyzed reaction in the absence of activator.

Many advantages are proper of the stop-flow technique applied to the in vitro evaluation of modulators of the CAs and include low cost, easy and direct execution of the experiments, high sensibility as well as data reliability. On the course of the years and with the progression of either technology and information technology the use of such instrumentation as well as data interpretation became easier to access and to validate with beneficial effects on the researchers conducted.

\section{Activation Studies on Human CAs}

\subsection{Natural and Synthetic Amino Acids and Amines}

Biogenic amines and amino acids are by far the most studied CA activators and represent the lead molecules for the design of new compounds endowed of this biological activity $[35,38]$. The kinetic data $\left(\mathrm{K}_{\mathrm{A}}\right)$, collected over the years profiling a pool of 19 amines and amino acids against the 13 catalytically active mammalians CAs (hCA I-XIV and murine (m) CA XV), allow us to draw some general observations about their activating properties and the possible contribution of CA activation to their complex biological activities (Figures 3 and 4) [38]. Five psychoactive substances, including amphetamine and mephentermine, have been also analyzed quite recently against 11 out of the 13 mammalian isoforms, revealing to be able to activate specific CA isoforms, with very low $\mathrm{K}_{\mathrm{A}}$ values showed by some of them [48]. These results could imply a possible contribution played by CAs in the cognitive effects of such molecules.

As for amino acids, both enantiomeric forms have been studied, revealing some isoforms to be more sensitive to a stereoisomer over the other (high eudysmic ratio). This enantioselective behavior is very interesting and only observed for some of the amino acids considered.

Strong enantioselectivity was shown by Phe, whose L-isomer 3 was largely more active on hCA I than its D-isomer $4\left(\mathrm{~K}_{\mathrm{A}}=0.07 \mu \mathrm{M}\right.$ and $86 \mu \mathrm{M}$, respectively). The latter was found to act as a better activator of CA VB $\left(\mathrm{K}_{\mathrm{A}}=0.07 \mu \mathrm{M}\right)$ and XIII $\left(\mathrm{K}_{\mathrm{A}}=0.05 \mu \mathrm{M}\right)$ instead, when compared to the L-analogue 3. The XIII isoform was better activated also by the D-isomer of $\operatorname{Trp} 6\left(\mathrm{~K}_{\mathrm{A}}=0.81 \mu \mathrm{M}\right)$, and the D-isomer of DOPA, $10\left(\mathrm{~K}_{\mathrm{A}}=0.81 \mu \mathrm{M}\right)$, whereas L-DOPA 9 showed higher selectivity for hCA VA and VB $\left(\mathrm{K}_{\mathrm{A}}=0.036\right.$ and $0.063 \mu \mathrm{M}$, respectively). hCA isoforms I, VA and VB and XIII were found therefore to be the most sensitive to the enantiomeric form of the amino acid considered. 


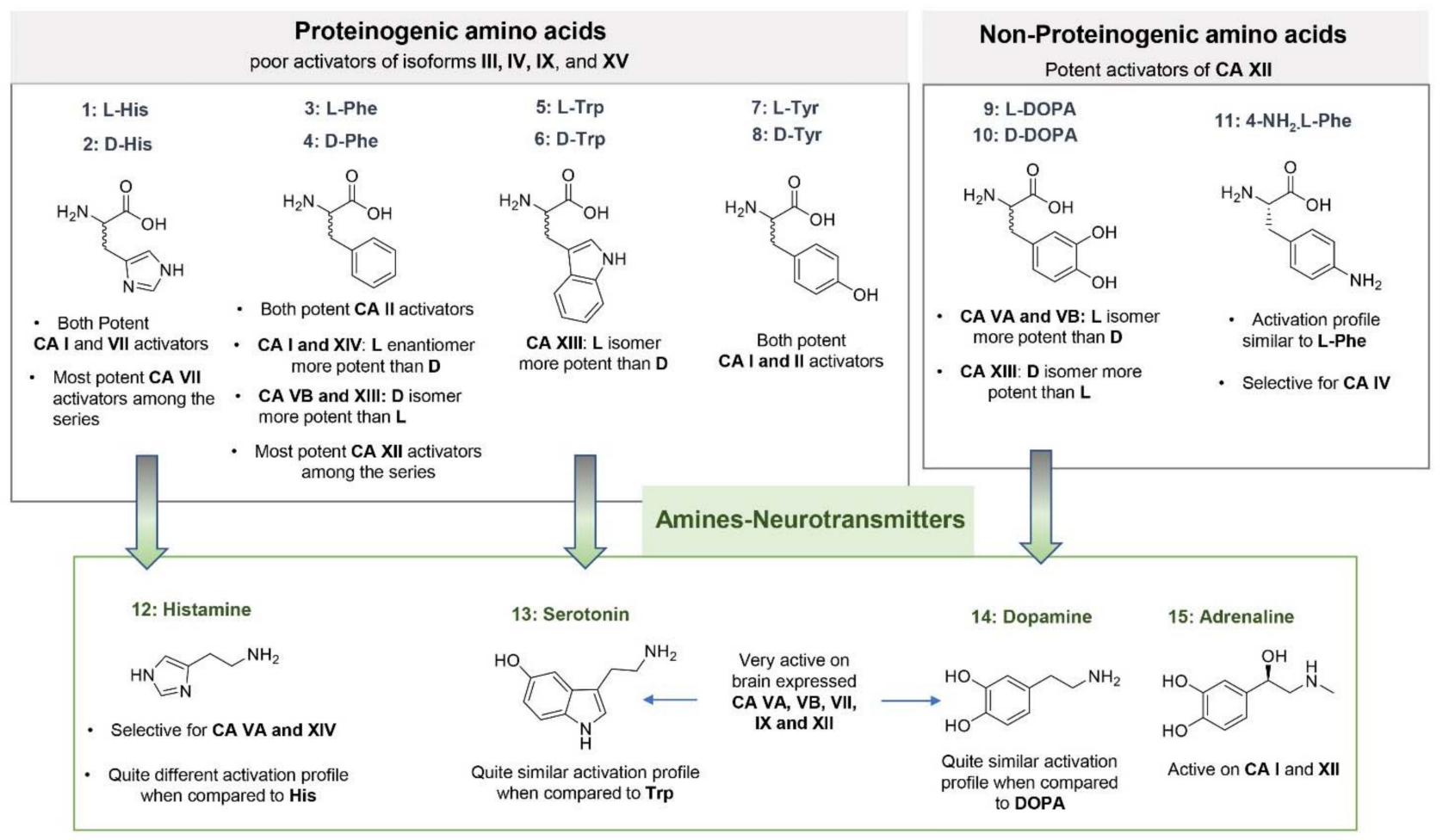

Figure 3. Natural and synthetic (11) amino acids and amines 1-15 investigated as CAAs.

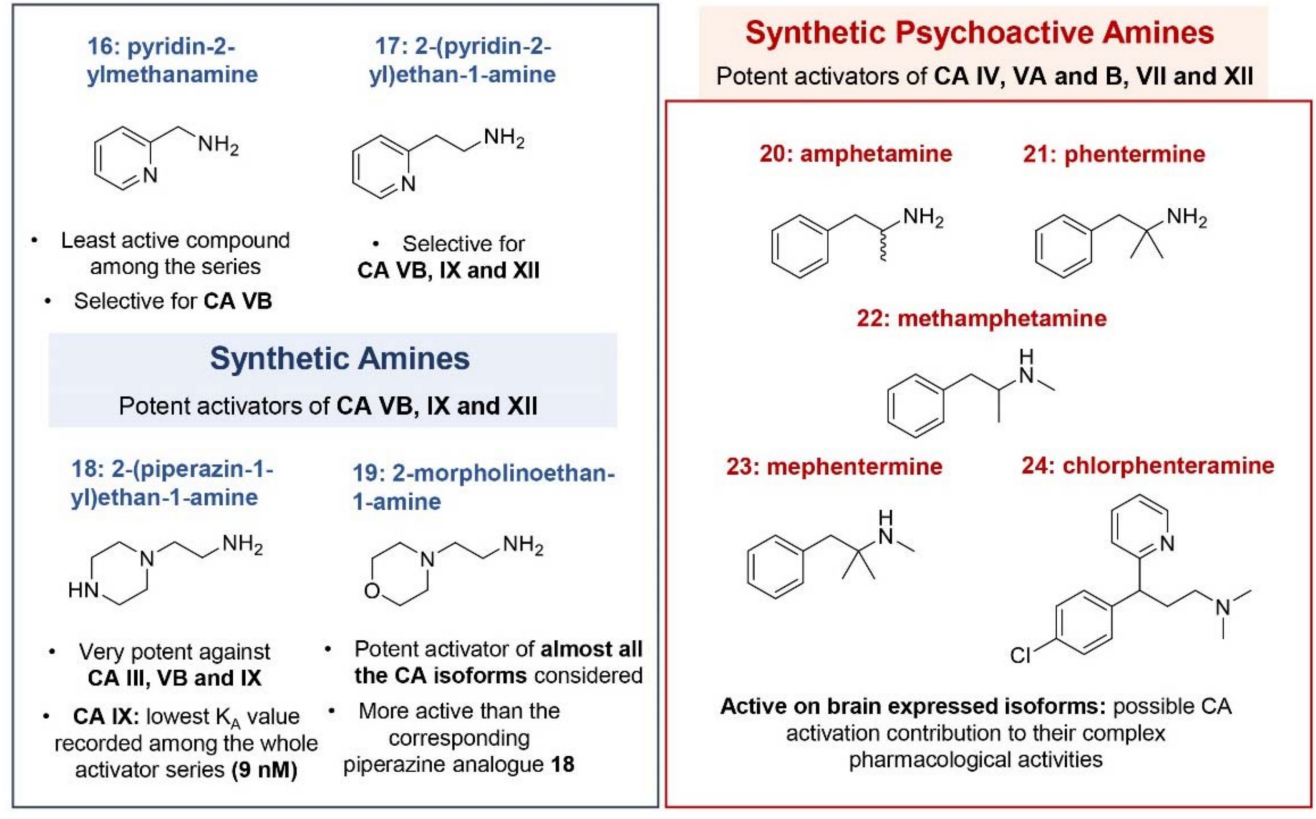

Figure 4. Synthetic amines 16-23 investigated as CAAs.

Noteworthy, D-Trp showed a strong selectivity for the hCA VA, VB and XIII among the panel of CA considered. Another interesting observation is that, among the amino acids, only L- and D-His showed significant activation properties towards hCA VII. This brain expressed isoform was instead strongly activated by DOPA and neurotransmitters 12-15, which showed also to potently activate mitochondrial isoforms hCA VA and B, and the transmembrane isoform hCA XII. This is a very important information considering the biological role of neurotransmitters. 
It is also interesting to observe that, when compared to their amino acidic precursors, some amines preserved the CA activating properties, showing a quite similar activation profile (i.e., Serotonin when compared to Trp), whereas for others (i.e., Histamine when compared to His) the activating properties against the CA isoforms considered were not retained. This phenomenon can be explained considering that for some amino acids (i.e., L-/D-His) the carboxylic group plays an important role in reinforcing the ligand binding to the target, as shown by the available co-crystallographic structures within hCA II $[37,39,43]$. In terms of biological meaning, these data could also contribute to confirm the different role and activities played by these endogenous molecules, probably mediated by different CA isoforms.

Synthetic amines 16-19 and psychoactive substances 20-24 both shared with neurotransmitters the poor activity against the cytosolic isoforms hCA I and II, and the low $\mathrm{K}_{\mathrm{A}}$ values against $\mathrm{hCA}$ VA and B. Specifically, synthetic amines 16-19 revealed to be very potent activators of hCA IX ( $\mathrm{K}_{\mathrm{A}}$ values ranging from $9 \mathrm{nM}$ to $\left.1.07 \mu \mathrm{M}\right)$, an isoform not (or very poorly) activated by all the other compounds considered so far. Morpholine compound 19, in particular, registered the lowest $\mathrm{K}_{\mathrm{A}}$ value among the series $(9 \mathrm{nM})$. As for psychoactive substances 20-24, stronger activity was observed against hCA IV, VA and VB, and CA VII, with $\mathrm{K}_{\mathrm{A}}$ values ranging in the high/medium nanomolar range [48]. Activation of brain expressed isoforms could contribute to the observed complex pharmacology of these substances. In general, very interesting behavior can be observed for some of the compounds here analyzed against hCAs, with a quite complementary activation profile showed by amines and amino acids. For completeness, a table reporting the $\mathrm{K}_{\mathrm{A}}$ values obtained for compounds 1-24 is here reported (Table 1).

Table 1. In vitro $\alpha$-CA activation data $\left(\mathrm{K}_{\mathrm{A}}\right)$ with amine derivatives and amino acids (1-24). Each value is the mean from three different determinations with errors in the range of $5-10 \%$ [38].

\begin{tabular}{|c|c|c|c|c|c|c|c|c|c|c|c|c|c|}
\hline \multirow{2}{*}{ cmpd } & \multicolumn{13}{|c|}{$K_{A}(\mu M)$} \\
\hline & hCA I & hCA II & hCA III & hCA IV & hCA VA & hCA VB & hCA VI & hCA VII & hCA IX & hCA XII & mCA XIII & hCA IV & mCA XV \\
\hline 1 & 0.03 & 10.9 & 35.9 & 7.3 & 1.34 & 0.97 & 32 & 0.92 & 9.71 & 37.5 & 0.13 & 0.9 & 32.1 \\
\hline 2 & 0.09 & 43 & 1.13 & 12.3 & 0.12 & 4.38 & 13 & 0.71 & 12.5 & 24.7 & 0.09 & 2.37 & 14.1 \\
\hline 3 & 0.07 & 0.013 & 34.7 & 36.3 & 9.81 & 10.45 & 1.23 & 10.93 & 16.3 & 1.38 & 1.02 & 0.24 & 33.4 \\
\hline 4 & 86 & 0.035 & 15.4 & 49.3 & 4.63 & 0.072 & 16 & 9.74 & 9.3 & 0.37 & 0.051 & 7.21 & 9.5 \\
\hline 5 & 44 & 27 & 20.5 & 37.1 & 1.13 & 0.89 & - & 57.5 & 37.5 & 23 & 16 & 16.5 & 13.5 \\
\hline 6 & 41 & 12 & 19 & 39.6 & 1.24 & 1.35 & - & 39.6 & 43.6 & 28.1 & 0.81 & 18 & 8.7 \\
\hline 7 & 0.02 & 0.011 & 34.1 & 25.1 & 2.45 & 0.044 & - & 20.3 & 25.3 & 25.8 & - & 21.8 & 8.9 \\
\hline 8 & 0.04 & 0.013 & - & - & - & - & - & - & - & - & - & - & - \\
\hline 9 & 3.1 & 11.4 & 13.5 & 15.3 & 0.036 & 0.063 & - & 58.3 & 51.3 & 1.67 & 43 & 12.1 & 6.5 \\
\hline 10 & 4.9 & 7.8 & 28.7 & 34.7 & 4.59 & 3.71 & - & 34.7 & 54.7 & 0.89 & 0.73 & 36.8 & 4 \\
\hline 11 & 0.24 & 0.15 & 43.2 & 0.079 & 2.76 & 2.17 & - & 18.7 & 48.7 & 1.09 & - & 2.9 & 16.3 \\
\hline 12 & 2.1 & 125 & 36.9 & 25.3 & 0.01 & 3.52 & 6.5 & 37.5 & 35.1 & 27.9 & 4.6 & 0.01 & 18.5 \\
\hline 13 & 45 & 50 & 0.78 & 3.14 & 6.33 & 0.11 & - & 0.93 & 33.1 & 0.3 & 0.51 & 6.5 & 7.5 \\
\hline 14 & 13.5 & 9.2 & 33.2 & 30.9 & 0.13 & 7.85 & 21.1 & 0.89 & 0.92 & 0.67 & 27 & 14.6 & 7.1 \\
\hline 15 & 0.09 & 96 & 36.4 & 45 & - & - & - & - & 60 & 0.87 & - & 36.1 & 6.9 \\
\hline 16 & 26 & 34 & 1.03 & 5.19 & 23.56 & 0.24 & - & 43.7 & 1.07 & 41.5 & 3.8 & 21.7 & 11.6 \\
\hline 17 & 13 & 15 & 1.1 & 7.13 & 7.62 & 0.094 & - & 27.8 & 0.013 & 0.69 & 46 & 6.9 & 11.9 \\
\hline 18 & 7.4 & 2.3 & 0.32 & 24.9 & 6.04 & 0.91 & 9.54 & 32.5 & 0.009 & 48.3 & 54 & 18.3 & 10.4 \\
\hline 19 & 0.14 & 0.19 & 0.091 & 1.3 & 0.089 & 1.15 & 42 & 64.3 & 0.43 & 0.24 & 0.013 & 5.4 & 9.3 \\
\hline 20 & $>150$ & $>150$ & - & 0.094 & 0.81 & 2.56 & $>150$ & 0.91 & $>150$ & 0.64 & 24.1 & 9.15 & - \\
\hline 21 & $>150$ & $>150$ & - & 0.074 & 0.53 & 0.62 & $>150$ & 0.89 & 34.6 & 3.24 & 54.2 & 12.7 & - \\
\hline 22 & $>150$ & $>150$ & - & 0.051 & 0.92 & 0.78 & $>150$ & 0.93 & $>150$ & 0.8 & 25.6 & 7.38 & - \\
\hline 23 & $>150$ & $>150$ & - & 1.03 & 0.37 & 0.24 & $>150$ & 0.64 & 25.8 & 6.12 & 48.3 & 18.1 & - \\
\hline 24 & $>150$ & $>150$ & - & 0.055 & 0.31 & 0.75 & $>150$ & 0.098 & 34.1 & 0.97 & 79.5 & 6.81 & - \\
\hline
\end{tabular}

-: not determined; cmpd: compounds. 
Although the SARs drawn for these compounds highlighted for some of them a preferential inhibition of an isoform over the others, for most of the amines and amino acids considered a quite flat activation profile can be observed. With the aim to enhance the selectivity towards specific $\mathrm{CA}$ isoforms and also to generate compounds with no structural relation with autacoids, many efforts have been made in the years by Medicinal Chemists in the field of CA activators, with different synthetic approaches developed so far.

\subsection{Synthetic Manipulations on Amines and Amino Acids}

Three main design strategies can be found looking at the available literature data (Figure 5). The most exploited drug design approach is represented by the synthesis of histamine analogues, which also included the synthesis of histamine inspired compounds. Another quite used lead is represented by the amino acid His and its $\beta$-alanine dipeptide derivative carnosine, along with other His-containing peptides. In the third group we included the compounds obtained applying different approaches, not strictly related to the parent natural amines/amino acids.

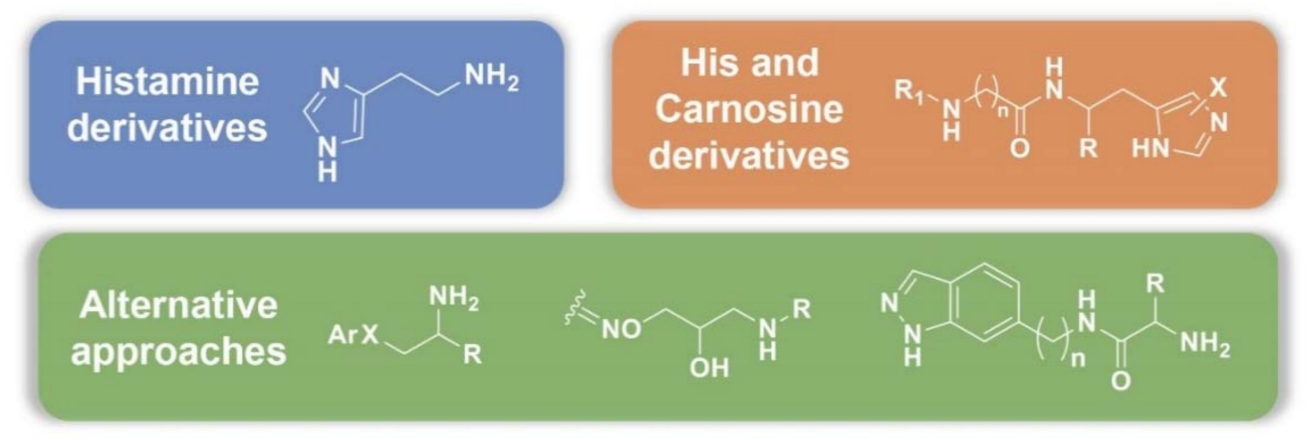

Figure 5. Main design strategies identified so far in the seek for potent and selective CAAs based on amines and amino acids.

Derivatization of the primary group of histamine can be listed among the first strategies reported in the literature for the design of histamine analogues (Figure 6). Crystallographic studies showed this function to point towards the exit of the cavity, thus not involved in the hydrogen bonding network responsible for the enzyme activation [37]. Carboxamides, triazoles, ureas or thioureas, sulfonamides, arysulfonylureido moieties, acylhistamines and bis-histamines incorporating EDTA moiety were all reported to possess a better activation profile against the isoforms I, II and IV when compared to histamine (compounds 25-31) [49-53]. Histamine Schiff bases incorporating aromatic, heterocyclic, or aliphatic moieties were also reported (e.g., compound 32) [54], as well as histamine pyridinium derivatives (e.g., compound 25), although their binding mode within hCA II showed to be very different from that usually observed for activators, even resembling the one of an inhibitor [55]. Primary amino group of histamine was also coupled with lipoic acid to be conjugated with gold nanoparticles (compound 33), resulting in a very strong CAs activation both in vitro and ex-vivo, in normal blood red cells [56]. Another early explored approach consisted in the replacement of imidazole ring of histamine with other ring systems, such as substituted pyridinium ring, 1,3,4-thiadiazole or a combination of the two (compounds 34-36, respectively) [57]. More recently, this strategy was revived by Rami et al., who designed (hetero)aryl substituted thiazol-2,4-yl derivatives incorporating pyridine as proton shuttling moiety (compounds $37 \mathbf{a}$ and $\mathbf{b}$ ) [58]. Very interesting results were obtained, with particular meaning for compound $37 \mathrm{~b}$, which showed to be very selective for CA VII, over CA I and II. 


\section{Derivatization of the primary amino group}<smiles>Cc1cc(C)[n+](CCc2c[nH]cn2)c(C)c1</smiles>

25<smiles>[R]C(N)C(=O)NCCc1c[nH]cn1</smiles>

26<smiles>[R]C(=O)NCCc1c[nH]cn1</smiles>

27
2. Replacing the imidazole

ring with other ring systems<smiles>O=C(NCCc1c[nH]cn1)NS(=O)(=O)[O-]</smiles>

28<smiles>[R]NC([X])NCCc1c[nH]cn1</smiles>

29

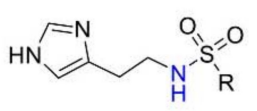

30<smiles>O=C(O)CN(CCN(CC(=O)O)CC(=O)NCc1c[nH]cn1)CC(=O)NCCc1c[nH]cn1</smiles><smiles>[R]C=NCCc1c[nH]cn1</smiles>

32

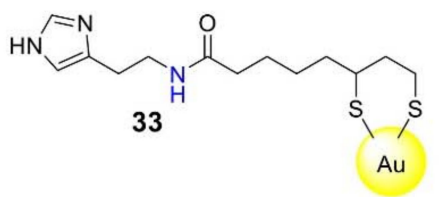

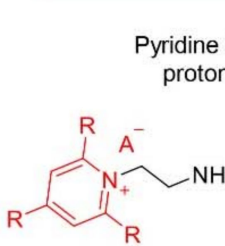

34
35<smiles>NCCc1nnc(N)s1</smiles>

36
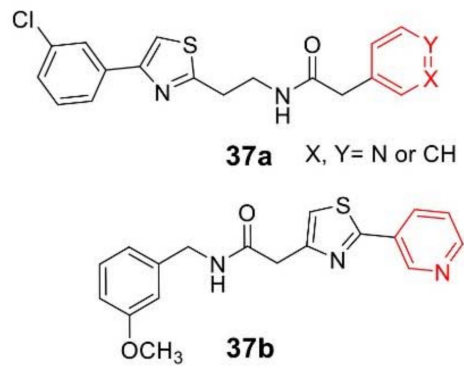

Figure 6. Synthetic analogues of histamine.

Another successful approach was represented by halogen(s) insertion on the imidazole ring, exploiting the withdrawing properties of halogens to affect compounds protonation state and the subsequent interaction with CA binding site (compounds 38 and 39, Figure 7) [59]. In particular, mono-halogenation gave better results than di-halogenation. Insertion of a second imidazole ring was also explored by Draghici et al., who designed bis-imidazoles of the type $\mathbf{4 0}$ in which the two imidazole rings were C-linked via an ethyl linker, bearing substituents of increased steric hindrance in the 2-position of the ring [60] (Figure 7). One imidazole moiety was inserted to work as proton-shuttle, whereas the other as anchoring point to CA active site rim. Small substituents placed in position $2\left(\mathrm{H}, \mathrm{CH}_{3}\right)$ led to very potent and selective hCA VA and VII activators, suggesting a different binding location of the imidazole ring depending on the isoform considered, driving the observed activation profile. Imidazole ring was found indeed to possess multiple binding sites within hCA II [61]. Following the same strategy, Akocak et al. also reported bis-histamine Schiff bases compounds, bearing different spacers between the two portions. Highly selective hCA VII derivative was represented by the furyl-containing compound 41 [62]. In the same work, the authors also explored the activating properties of bis-spinaceamine derivatives, representing the ring closure products of bis-histamine Schiff bases (compounds of the type 49). A series of diverse substituted spinaceamine derivatives, which can be considered as an "histamine-inspired compound", was previously reported by the same authors and the compounds profiled as CA activators, showing nanomolar potencies against hCA VII [63]. Analogously, bis-spinaceamine derivatives showed high potency and selectivity against this isoform, with no significant differences observed among the reported compounds, bearing different spacers between the two active portions. Quantum mechanical (QM) calculations were very recently performed on some of these bis-histamine Schiff bases and bis-spinaceamines, indicating that the activator participates to the proton-shuttling process 
from the zinc-bound water molecule to the medium and that the electrostatic interactions between the activators and hCA VII are the driving force of the enzyme-activator complex formation [64]. L-(+)-Ergothioneine 42, Melatonin 43 and Spinacine 44 as well as synthetic compounds 45-47, recently studied as CA activators, should be also mentioned among the histamine inspired compounds (Figure 7) [65]. A strong selectivity for the abundantly CNS expressed hCA VII was observed also for these compounds, which showed to be 10 times more potent than the reference compound histamine. The in vitro results were also corroborated by docking studies [65].

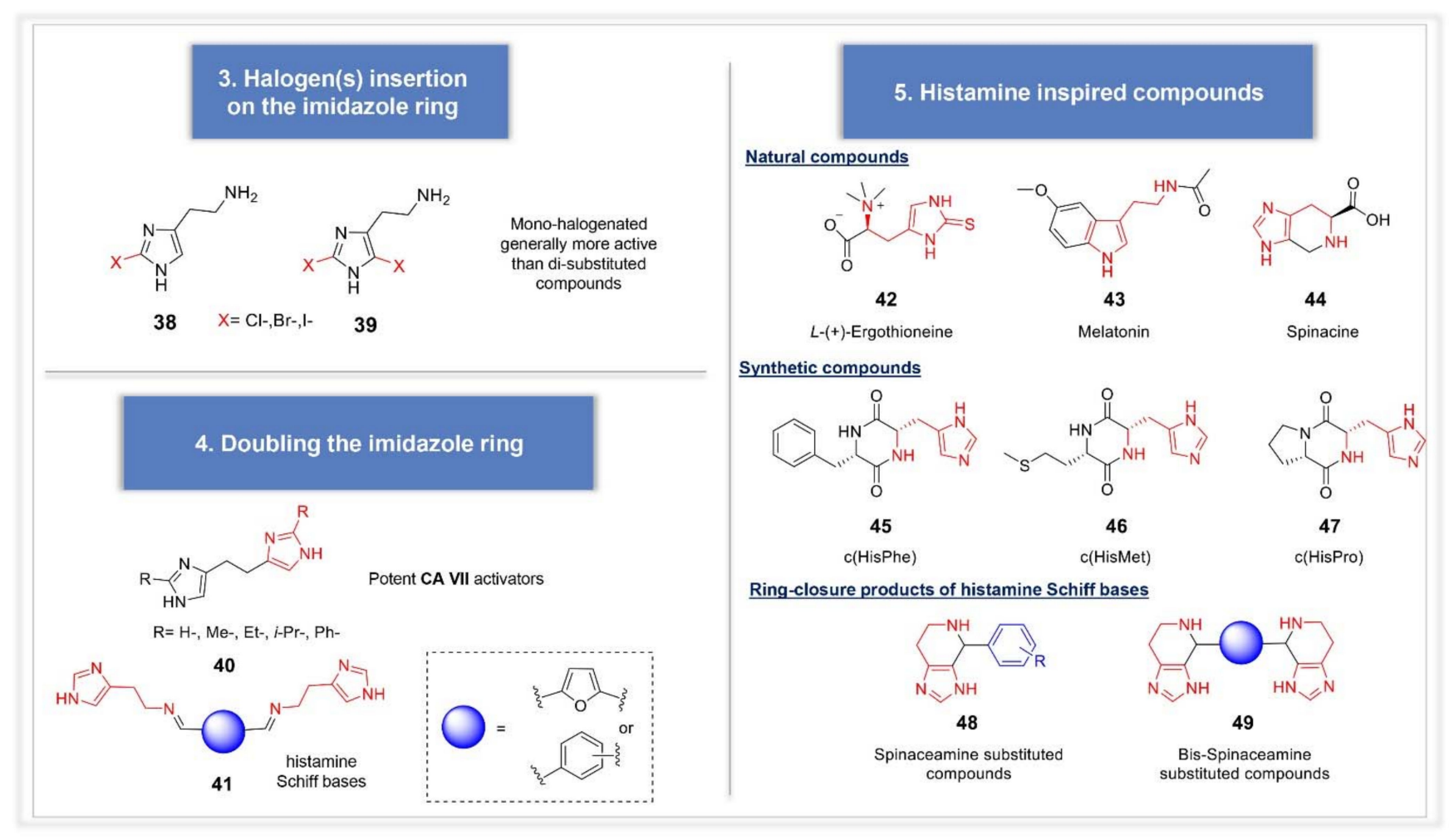

Figure 7. Synthetic analogues of histamine.

Finally, a large library of histamine receptors $\left(\mathrm{H}_{1} \mathrm{R}-\mathrm{H}_{4} \mathrm{R}\right)$ agonists, antagonists and histamine derivatives have recently been profiled against five pharmacologically relevant hCA isoforms, expressed in human brain [66]. Very different potencies and selectivity profiles were observed, most of them showing very low $\mathrm{K}_{\mathrm{A}}$ values against hCA VII. As expected, compounds devoid of the imidazole moiety or, more in general, of a histaminerelated scaffold, did not activate at all the analyzed CAs $\left(\mathrm{K}_{\mathrm{A}}>100 \mu \mathrm{M}\right)$. The hCA activation property observed for some of these clinically used compounds could explain some of the side effects observed for some of them, or at least contribute to a better understanding of their polypharmacology.

Another quite well explored lead molecule in the field of CAAs is represented by the amino acid histidine and its $\beta$-alanine dipeptide derivative, carnosine. In analogy with histamine, derivatization of the primary amino group of histidine was among the earliest approaches explored. A large set of His and carnosine arylsulfonylureido derivatives was reported in 2002 (compound 53 as representative for the series, Figure 8) [67]. In this study, which provides also the first report of L-carnosine effects on hCAs, very potent derivatives were identified. In particular, compounds incorporating basic amino acids (i.e., Arg or Lys), as well as longer tetrapeptide scaffolds, showed activation constants falling in the nanomolar range. Another synthetic approach explored by Abdo et al. consisted in the synthesis of arylsulfonylhydrazido-L-histidine derivatives, incorporating 4-substituted aryl moieties [68]. This strategy led to compounds less potent than His, with the only 
exception represented by compound $\mathbf{5 2}$, for which a $\mathrm{K}_{\mathrm{A}}$ constant of $0.21 \mu \mathrm{M}$ was recorded against hCA II. Conjugation with lipoic acid to obtain His and Carnosine gold nanoparticles were explored too, as described above for histamine (compounds 53 and 54, Figure 8) [56]. Halogenation of the imidazole ring of histidine and carnosine was also reported by Saada et al., obtaining compounds of the types $\mathbf{5 0}$ and $\mathbf{5 1}$, endowed with different selectivity [69]. Halogenated His derivatives were more potent against hCA I and II, whereas for carnosine this chemical modification improved the activity against hCA VII. A recent study by Vistoli and co-workers, extended the panel of histidine containing peptides to be studied as CAAs, including both natural and synthetic derivatives (compounds 56-60, Figure 8) [70]. The reported compounds were evaluated against hCA I, hCA II, hCA VA and hCA IX, and the obtained data rationalized by docking simulations on hCA II, chosen as model enzyme. The results confirmed the role played by the imidazole ring in affecting the CA activating potencies, while derivatization on the $\mathrm{C}$ - and/or $\mathrm{N}$-termini appears to play a more marginal role, mostly affecting the isoform selectivity.

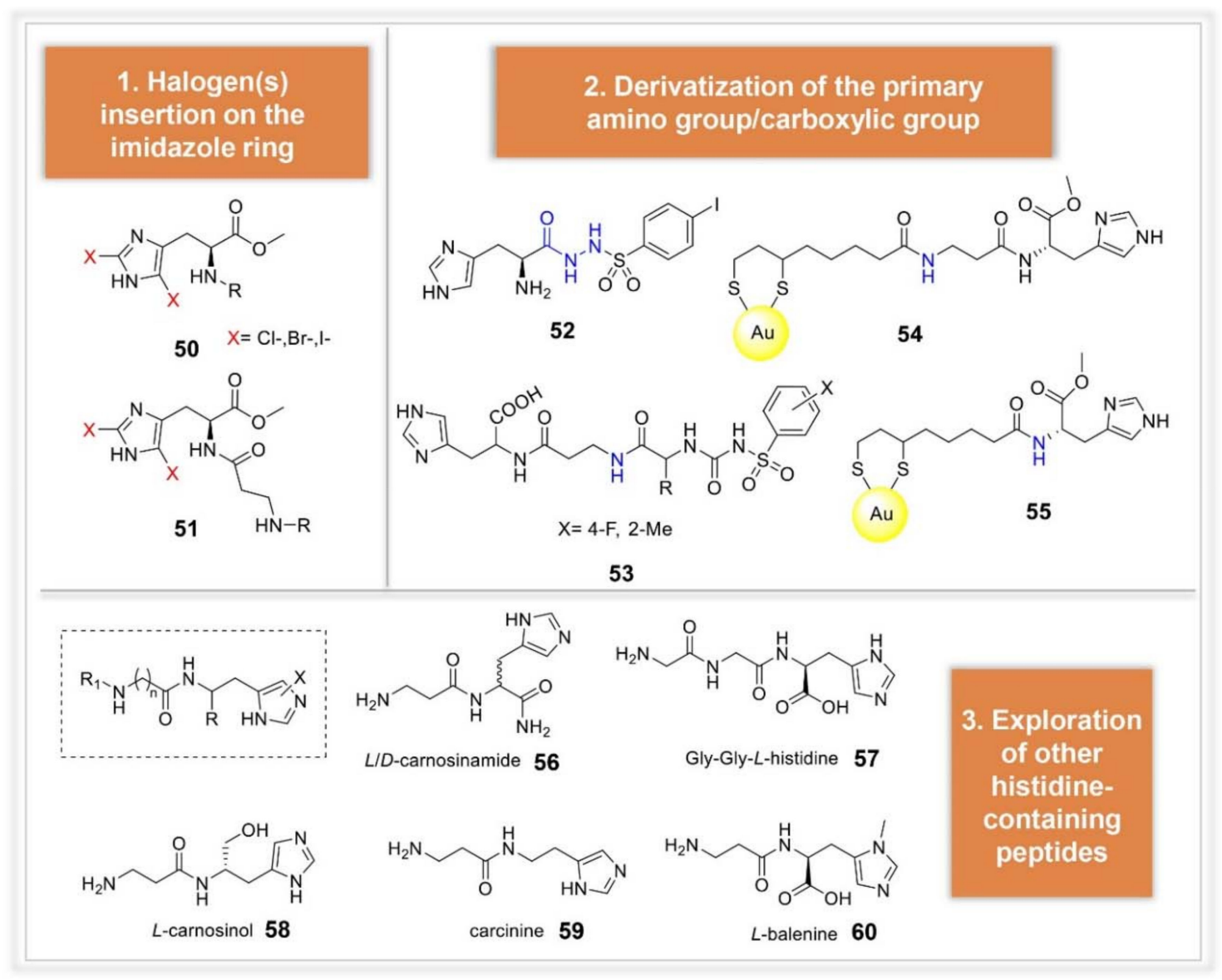

Figure 8. Histidine analogues and histidine containing peptides studied as CAAs.

Alternative and unconventional approaches for the design on new CAAs were recently reported in the literature by different groups. In 2019, Tanini et al. reported the synthesis and biological evaluation of organic chalcogenides structurally related to the psychoactive drug amphetamine (compounds 61-63, Figure 9) [71]. Compounds were obtained by ring opening of strained aziridine with chalcogen nucleophiles, to give $\beta$-arylchalcogeno amines containing sulfur, selenium and tellurium. This quite large series showed good activating properties against the isoforms hCA I, VA and VII and a potent antioxidant activity, especially for selenium and tellurium compounds, which were able to prevent ROS metabolites generation and the consequent cellular stress and damage. These compounds are, therefore, of great interest in the field of neurodegenerative disorders treatment, where 
the levels of ROS are particular high. More recently, a large series of amino alcohol was reported by Nocentini et al. obtained by ring opening of differently substituted epoxydic oxime ethers with isopropylamine or tert-butylamine [72]. These compounds were designed using as lead the $\beta$-amino alcohol timolol, previously found to act as CAA [73]. The synthetized compounds were assayed as CAAs against four physiologically relevant hCA isoforms expressed in human brain, showing $\mathrm{K}_{\mathrm{A}}$ values spanning from the low micromolar to the medium nanomolar range. Compounds 64 and 65 in particular revealed to be highly selective for the isoform CA II and VII, respectively, opening new perspectives in the design of potent and selective CAAs based on the amino alcohol scaffold, as valid alternative to amines and amino acids [72] (Figure 9).

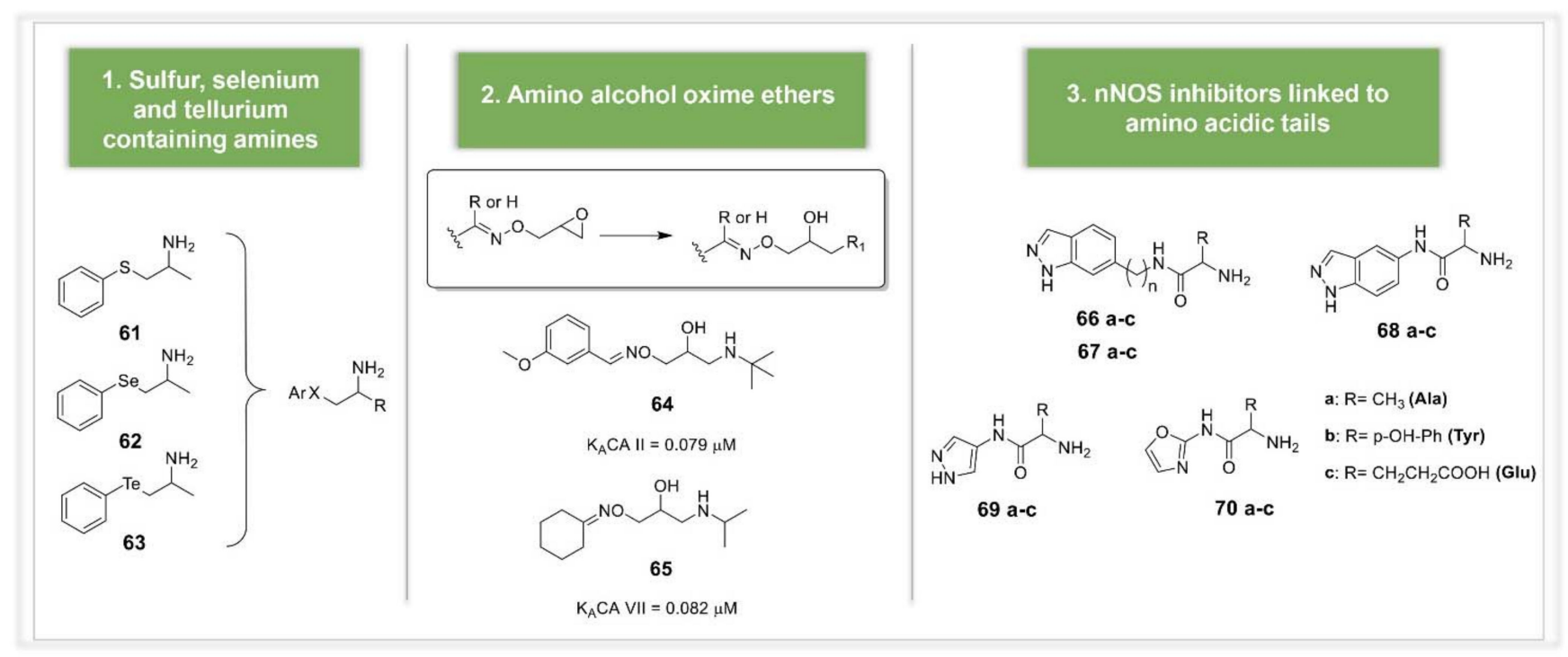

Figure 9. Alternative approaches for the design of CAAs.

Another novel approach was reported by Maccallini et al., who designed indazole, pyrazole, and oxazole derivatives bearing amino acidic tails, such as alanine (Ala), tyrosine (Tyr), and glutamic acid (Glu) (compounds 66-70, Figure 9) [74]. This strategy was based on the well-known property of heterocyclic compounds and amino acids to activate CAs, coupled to the ability of indazole, pyrazole, and oxazole derivatives to inhibit neuronal nitric oxide synthase (nNOS). These two biological activities could make the designed compounds valuable drug candidates for the treatment of neurodegenerative disorders (i.e., Alzheimer's disease (AD), Parkinson's disease (PD)), where an abnormal nitrergic signal was observed, along with a low CA expression, affecting cognition and leading to mental retardation. Among the series, 5 -substituted indazole derivative $\mathbf{6 8 b}$ containing Tyr as CAA moiety showed to be the most promising dual agent, selectively inhibiting nNOS (over iNOS and eNOS) and activating hCA I.

\section{Therapeutic Applications for Human Health}

As above mentioned, CAAs main therapeutic applications for human diseases are in the field of pharmacological enhancement of synaptic efficiency, spatial learning, and memory. Involvement of CAs in cognitive function was already proposed by Sun and Alkon [75,76], whose theories were supported by previous evidence of a significantly diminished activity of CAs in patients affected with $\mathrm{AD}$, when compared to age-matched controls [77]. These studies have been resumed by Blandina's group, who investigated from a mechanistic point of view CA involvement in cognition [66,78-80]. In particular, the importance of $C A$ activity in spatial and fear memory formation was demonstrated by using blood brain barrier (BBB) permeant (AAZ) and impermeant (C18, a pyridinium perchlorate compound) CA inhibitors, and a CAA, D-Phe. Permeant but not impermeant inhibitor, 
which does not cross the BBB, was able to impair short-term novel object recognition memory and consolidation of fear extinction memory. CA activation using D-phenylalanine led instead to improved performances in memory task, generating a long-term memory that persists up to $24 \mathrm{~h}$ after training. CA activation has therefore a crucial role in transforming short-term learning into long-lasting memory, and this effect was related to CA activationdependent increased pERK expression, as one of the possible CAA underlying mechanisms (Figure 10) [78]. Activation of ERK pathways in the cortex and in the hippocampus triggers the genomic response in neurons and leads to structural synaptic changes that facilitate memory encoding [81]. Analogously, in fear memory extinction models the selective inhibition of CAs in the brain correlates with impairments of extinction whereas activation has beneficial effects.

(A)

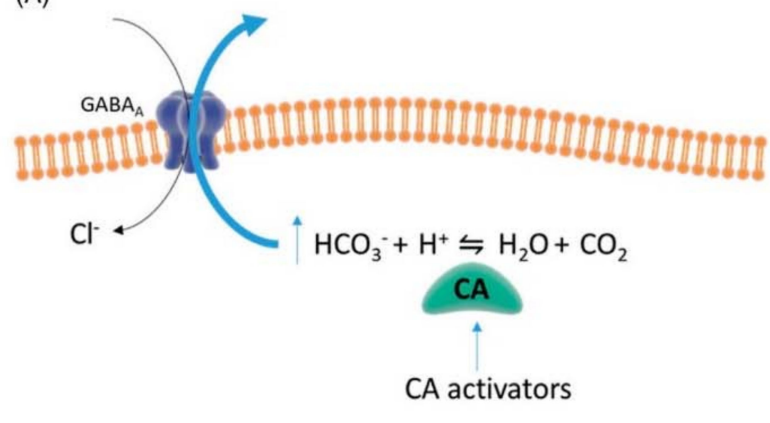

(B)

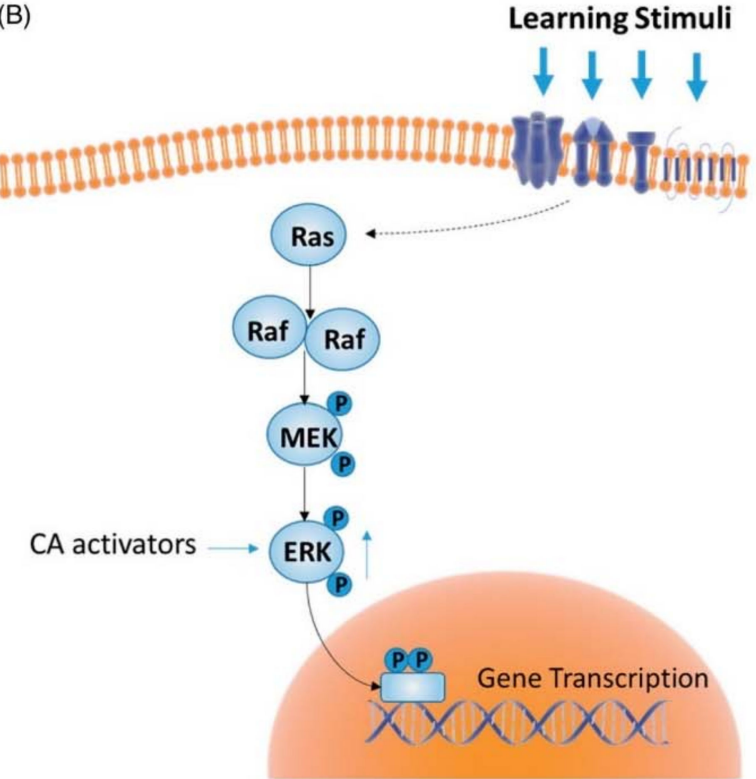

Figure 10. Putative mechanisms underpinning CAs actions on cognition. (A) CA activation transforms GABA-mediated inhibition $\left(\mathrm{Cl}^{-}\right.$conductance) into excitation due to increased $\mathrm{HCO}_{3}{ }^{-}$flux through the $\mathrm{GABA}_{\mathrm{A}}$ receptor channel. Such synaptic transformation allows GABA-releasing interneurons to act as either excitation filters or amplifiers of the neuronal network [76]. (B) CA activators increase ERK phosphorylation [78], which in turn regulates the activity of nuclear transcription factors promoting gene transcription, an essential step for consolidation of different learning stimuli [81]. The CA isoforms as well as the cellular mechanisms related to CA-induced modulation of ERK activity were not identified yet. Reproduced from [80].

These studies pave the way for pharmacological application of CAAs in the management of post-traumatic stress disorders (PTSD), phobias and generalized anxiety. Potentially, CAAs could be also considered as future new tools for the treatment of memory associated symptoms from neurodegenerative diseases and aging. Another very interesting application of CAAs is in the field of tissue engineering, mainly explored by Müller's group $[82,83]$. Carbonate deposition is animals (i.e., mollusk shells) is known to rely on the CA-driven $\mathrm{HCO}_{3}{ }^{-}$formation as rate limiting step. Studies on human osteogenic SaOS-2 cells exposed to $\mathrm{Ca}\left(\mathrm{HCO}_{3}\right)_{2}$ in vitro revealed an increase of Ca-deposit formation and upregulation of the CA II gene expression. Moreover, addition of a CA inhibitor (AAZ) prevented Ca-deposit formation [83]. Using sponges as a biological starting material, the presence of CA activators led to an enhanced formation of calcium carbonate, which acts as bioseeds for the precipitation of calcium phosphate, in the bone formation process [82]. The discovery that $\mathrm{CAs}$ are highly involved in $\mathrm{CaCO}_{3}$ deposition in vitro and likely in vivo opened the way to the exploration of CAAs for increasing bone formation. 


\section{Natural and Synthetic Amino Acids and Amines Activating Non-Human CAs}

The last review on these biomolecules was elegantly reported by Akocak and Supuran in 2019 [3], but due to the overwhelming published literature, we performed an update including the most recent discoveries in this field. The development of non-human CAAs has been much limited due to their complicated pharmacology and catalytic cycle (e.g., $\mathrm{Zn}$ (II) can be substituted by other metal ions or can be catalytically inactive) compared to the design of CAIs (Table 2). Indeed, the extrapolation of SARs is rather complex compared to human enzymes due to the differences in the active site of the isozymes present in a large number of organisms.

Table 2. Non-human species characterized by different CA families and tested for the activation mechanism.

\begin{tabular}{|c|c|c|}
\hline Species & CA Family (Acronym) & Ref. \\
\hline \multicolumn{3}{|c|}{ Gram-Positive and Gram-Negative Bacteria } \\
\hline $\begin{array}{l}\text { Sulfurihydrogenibium } \\
\text { yellowstonense }\end{array}$ & $\alpha(\mathrm{SSpCA})$ & {$[84]$} \\
\hline Sulfurihydrogenibium azorense & $\alpha(\mathrm{SazCA})$ & \\
\hline Vibrio cholerae & $\begin{array}{c}\alpha(\mathrm{VchCA} \alpha), \beta(\mathrm{V} \operatorname{chCA} \beta), \\
\text { and } \gamma(\mathrm{V} \operatorname{chCA} \gamma)\end{array}$ & [85-87] \\
\hline Mycobacterium tuberculosis & $\beta(\mathrm{mtCA} 3$ or $\mathrm{Rv} 3273 \mathrm{CA})$ & {$[87,88]$} \\
\hline $\begin{array}{l}\text { Methanobacterium } \\
\text { thermoautotrophicum }\end{array}$ & $\beta(\mathrm{Cab})$ & [89] \\
\hline Escherichia coli & $\beta(\operatorname{EcoCA} \beta)$ & [90] \\
\hline Brucella suis & $\beta$ (BsuCA1) & [91] \\
\hline Francisella tularensis & $\beta$ (FtuCA) & [91] \\
\hline Burkholderia pseudomallei & $\beta(\mathrm{BpsCA} \beta)$ & \\
\hline Methanosarcina thermophila & $\gamma(\mathrm{Cam})$ & [89] \\
\hline Burkholderia pseudomallei & $\gamma(\mathrm{Bps} \gamma \mathrm{CA})$ & {$[87,92]$} \\
\hline Pseudoalteromonas haloplanktis & $\gamma($ PhaCA) & [93] \\
\hline Colwellia psychrerythraea & $\gamma(\mathrm{CpsCA})$ & [93] \\
\hline Burkholderia territorii & i(BteCAi) & {$[94]$} \\
\hline \multicolumn{3}{|c|}{ Fungi and Yeasts } \\
\hline Saccharomyces cerevisiae & $\beta(\mathrm{scCA})$ & [95] \\
\hline Candida albicans & $\beta$ (CaNce103) & [96] \\
\hline Cryptococcus neoformans & $\beta($ Can 2$)$ & [96] \\
\hline Candida glabrata & $\beta(\mathrm{CgCA})$ & [97] \\
\hline Malassezia globosa & $\beta$ (MgCA) & [98] \\
\hline Malassezia restricta & $\beta$ (MreCA) & [99] \\
\hline \multicolumn{3}{|c|}{ Protozoa } \\
\hline Trypanosoma cruzi & $\alpha(\mathrm{TcCA})$ & [100] \\
\hline Leishmania donovani chagasi & $\beta$ (LdcCA) & [101] \\
\hline Entamoeba histolytica & $\beta$ (EhiCA) & [102] \\
\hline Trichomonas vaginalis & $\beta$ (TvaCA1) & [103] \\
\hline Plasmodium falciparum & $\eta($ PfACA) & [104] \\
\hline \multicolumn{3}{|c|}{ Microalgae } \\
\hline Thalassiosira weissflogii & $\delta($ TweCA $\delta)$ and $\zeta($ TweCA $\zeta)$ & {$[19,105]$} \\
\hline \multicolumn{3}{|c|}{ Corals } \\
\hline Corallium rubrum & $\alpha(\mathrm{CruCA} 4)$ & [106] \\
\hline Stylophora pystillata & $\alpha(\mathrm{STPCA})$ & [107] \\
\hline
\end{tabular}

As seen above, the most extensively studied CAAs usually belong to amines and amino acids as chemical scaffolds and compounds 1-19 (Figure 1) were always tested for their activation of non-human CA isoforms. Moreover, other amino acids (71-75, Figure 11) were recently introduced to better understand the general structural requirements for 
such activity. The use of the same panel of activators by the same research group can be considered a straightforward strategy to rationalize the differences within the series of related targets and to gain more robust information about the impact of the stereochemistry in the biological interaction.<smiles>NC(=O)C[C@H](N)C(=O)O</smiles>

71

L-Asn<smiles>N[C@@H](CC(=O)O)C(=O)O</smiles>

72

L-Asp<smiles>N[C@@H](CCC(=O)O)C(=O)O</smiles>

73 L-Glu 74 D-Glu<smiles>N[C](CCC(N)=O)C(=O)O</smiles>

75 L-Gln

Figure 11. Amino acids 71-75 recently introduced to better study the activation mechanism of non-human CAs.

Lastly, tripeptides were also designed to enlarge the chemical space suitable for the activation of these enzymes.

From a synthetic point of view, non-human CAs activators are not obtained by means of sophisticated organic reactions, because their structures are largely derived from natural amino acids. A recent and promising approach could come from dynamic constitutional strategies developed to produce enzyme-dynamic combinatorial systems using simple synthetic building blocks with a high rate of variability and versatility [108]. Collectively, the knowledge of the $\mathrm{K}_{\mathrm{A}}$ values of these derivatives, not only regarding the human CAs but also considering the non-human isozymes, allowed us to assess the most essential chemical functions to achieve a good selectivity index. Indeed, for comparative purposes, we have also reported $\mathrm{K}_{\mathrm{A}}$ values obtained with the most ubiquitous $\alpha$-CAs isoforms (CA I and II) reported at paragraph 3 . The criteria for selectivity are important due to the fact that non-human CAs are present in seven out of the eight different genetic families known to date (only $\theta$-CAs identified in marine diatoms are unexplored yet for activators), isolated from pathogenic and non-pathogenic organisms.

The CA activation in these species, albeit not useful for therapeutic use, can improve our understanding of the catalytic mechanism or the involvement of the proton shuttling as in human CAs. In pathogenic species, this information strengthens the functional role of their specific CAs about evolution, survival, metabolism and virulence, providing comprehension of how these factors are influenced by modulators of CA activity to develop new therapeutic strategies avoiding drug resistance that has emerged for most clinically used anti-infectives.

On the other hand, CAs from coral, such as CruCA4, were shown to be involved in the biomineralization process and in vivo enhanced growth rates of coral skeletons [106]. Conversely, in diatoms these CAs seem to be involved in the carbon acquisition pathway leading to a hydrolase activity of different substrates [109]. Finally, the thermostable and very active $\alpha$-CAs from the thermophilic bacteria Sulfurihydrogenibium yellowstonense YO3AOP1 and Sulfurihydrogenibium azorense (SazCA) provided industrial applications for biomimetic $\mathrm{CO}_{2}$ capture processes [84].

For sake of clarity, we have collected the kinetic data of compounds 1-19 to define preliminary SARs clustered in families, keeping into consideration the lack of X-ray crystal structures of CAAs in complex with any CAs other than hCA II (Tables 3-6). 
Table 3. In vitro $\alpha$-CA activation data $\left(\mathrm{K}_{\mathrm{A}}\right)$ with a panel of amine derivatives and amino acids (1-19). Each value is the mean from three different determinations with errors in the range of $5-10 \%$.

\begin{tabular}{|c|c|c|c|c|c|c|}
\hline \multirow{2}{*}{ Compound } & \multicolumn{6}{|c|}{$\mathrm{K}_{\mathrm{A}}(\mu \mathrm{M})$} \\
\hline & STPCA & CruCA4 & $\mathrm{V} \operatorname{chCA} \alpha$ & SspCA & TcCA & SazCA \\
\hline 1 & 28.0 & 36.9 & 43.2 & 0.11 & 11.3 & 0.071 \\
\hline 2 & 26.0 & 0.098 & 22.7 & 0.012 & 7.5 & 0.090 \\
\hline 3 & 34.0 & 15.4 & 53.6 & 0.008 & 12.1 & 0.062 \\
\hline 4 & 21.0 & 1.0 & 34.5 & 5.1 & 6.4 & 0.009 \\
\hline 5 & 3.2 & 9.5 & 4.1 & 0.007 & 2.5 & 0.004 \\
\hline 6 & 19.0 & 8.3 & 38.0 & 0.002 & 1.8 & 0.89 \\
\hline 7 & 31.0 & 0.73 & 8.2 & 0.01 & 4.9 & 0.023 \\
\hline 8 & nd & 18.9 & 37.8 & 0.83 & 2.8 & 0.003 \\
\hline 9 & 15.0 & 13.7 & 23.1 & 0.09 & 0.83 & 0.052 \\
\hline 10 & 0.18 & 0.93 & 19.4 & 0.43 & 0.38 & 0.11 \\
\hline 11 & 10.1 & 0.074 & 41.6 & 0.97 & 0.75 & 0.09 \\
\hline 12 & $>100$ & 0.007 & 9.1 & 0.08 & 2.7 & 0.10 \\
\hline 13 & 56.0 & 0.006 & 11.7 & 0.021 & 2.0 & 0.011 \\
\hline 14 & 89.0 & 0.005 & 35.2 & 0.037 & $>100$ & 0.007 \\
\hline 15 & 47.0 & 0.009 & 18.2 & 0.68 & $>100$ & 0.081 \\
\hline 16 & $>100$ & 0.41 & 68.3 & 0.10 & $>100$ & 0.34 \\
\hline 17 & $>100$ & 0.26 & 71.9 & 0.33 & $>100$ & 0.076 \\
\hline 18 & 11.5 & 0.004 & 57.3 & 0.09 & $>100$ & 1.15 \\
\hline 19 & 64.0 & 0.15 & 12.0 & 0.10 & 0.14 & 0.074 \\
\hline
\end{tabular}

nd: not determined.

Table 4. In vitro fungal $\beta$-CAs activation data $\left(\mathrm{K}_{\mathrm{A}}\right)$ with amine derivatives and amino acids (1-19). Each value is the mean from three different determinations with errors in the range of $5-10 \%$.

\begin{tabular}{|c|c|c|c|c|c|c|}
\hline \multirow{2}{*}{ Compound } & \multicolumn{6}{|c|}{$\mathrm{K}_{\mathrm{A}}(\mu \mathrm{M})$} \\
\hline & scCA & CaNce103 & CgCA & Can2 & $\mathrm{MgCA}$ & MreCA \\
\hline 1 & 82.0 & 24.1 & 37.0 & 45.0 & 29.3 & 12.8 \\
\hline 2 & 85.0 & 19.5 & 21.2 & 47.2 & 18.1 & 1.8 \\
\hline 3 & 86.0 & 15.5 & 24.1 & 44.1 & 34.1 & 3.0 \\
\hline 4 & 86.0 & 8.4 & 15.7 & 45.2 & 10.7 & 0.76 \\
\hline 5 & 91.0 & 19.2 & 22.8 & 28.7 & 10.1 & 0.32 \\
\hline 6 & 90.0 & 43.0 & 12.1 & 42.1 & 12.5 & 0.89 \\
\hline 7 & 85.0 & 46.1 & 9.5 & 29.5 & 15.7 & 4.1 \\
\hline 8 & 84.0 & nd & 7.1 & nd & 25.1 & 7.8 \\
\hline 9 & 90.0 & 0.96 & 23.3 & 43.3 & 8.31 & 0.87 \\
\hline 10 & 89.0 & 2.5 & 15.1 & 35.1 & 13.7 & 0.70 \\
\hline 11 & 21.3 & 23.7 & 31.6 & 30.4 & 13.4 & 0.61 \\
\hline 12 & 20.4 & 18.4 & 27.4 & 33.2 & 10.9 & 0.90 \\
\hline 13 & 15.0 & 28.6 & 16.7 & 46.7 & 14.2 & 0.82 \\
\hline 14 & 13.1 & 18.5 & 27.6 & 34.6 & 9.43 & 2.7 \\
\hline 15 & 0.95 & 13.2 & 10.8 & 32.8 & 0.72 & 0.015 \\
\hline 16 & 16.2 & 29.1 & 15.0 & 47.0 & 6.1 & 0.34 \\
\hline 17 & 11.2 & 30.2 & 16.3 & 46.3 & 7.3 & 2.1 \\
\hline 18 & 9.3 & 17.3 & 14.9 & 44.9 & 0.81 & 0.25 \\
\hline 19 & 10.2 & 25.4 & 10.1 & 40.1 & 5.8 & 0.33 \\
\hline
\end{tabular}


Table 5. In vitro other $\beta$-CAs activation data $\left(K_{A}\right)$ with amine derivatives and amino acids (1-19). Each value is the mean from three different determinations with errors in the range of $5-10 \%$.

\begin{tabular}{|c|c|c|c|c|c|c|c|c|c|c|}
\hline \multirow{2}{*}{ Compound } & \multicolumn{10}{|c|}{$\mathrm{K}_{\mathrm{A}}(\mu \mathrm{M})$} \\
\hline & Cab & mtCA3 & $\mathrm{V} \operatorname{chCA} \beta$ & $\mathrm{E} \operatorname{coCA} \beta$ & BsuCA1 & FtuCA & LdcCA & EhiCA & TvaCA1 & BpsCA $\beta$ \\
\hline 1 & 69.0 & 18.2 & 20.3 & 36.0 & 1.8 & 40.7 & 8.2 & 78.7 & 20.1 & 31.6 \\
\hline 2 & 57.0 & 32.5 & 18.0 & 23.7 & 12.3 & 78.3 & 4.1 & 9.8 & 24.5 & 0.98 \\
\hline 3 & 70.0 & 30.6 & 15.4 & 12.0 & 1.2 & 69.1 & 9.2 & 16.5 & 23.6 & 3.42 \\
\hline 4 & 10.3 & 44.1 & 5.1 & 15.4 & 1.1 & 75.0 & 3.9 & 10.1 & 16.3 & 0.075 \\
\hline 5 & 16.9 & 8.9 & 4.2 & 18.3 & 1.2 & 34.1 & 4.0 & 5.2 & 5.1 & 0.009 \\
\hline 6 & 41.0 & 43.7 & 5.9 & 11.5 & 13.7 & 30.5 & 6.2 & 4.9 & 3.6 & 0.007 \\
\hline 7 & 10.5 & 28.9 & 6.1 & 9.9 & 1.4 & $>100$ & 8.1 & 4.5 & 4.9 & 0.002 \\
\hline 8 & 19.2 & 17.6 & 0.94 & 17.9 & 0.95 & $>100$ & 1.3 & 1.1 & 3.0 & 0.001 \\
\hline 9 & 11.4 & 30.0 & 8.4 & 10.7 & 2.1 & $>100$ & 1.6 & 16.6 & 12.1 & 0.003 \\
\hline 10 & 15.6 & 9.7 & 6.3 & 3.1 & 2.3 & 44.8 & 5.5 & 4.1 & 11.0 & 1.89 \\
\hline 11 & 89.0 & 40.5 & 7.2 & 7.3 & 1.2 & $>100$ & 15.9 & 8.1 & 3.5 & 0.0009 \\
\hline 12 & 76.0 & 34.2 & 9.5 & 18.5 & 3.7 & $>100$ & 0.74 & 7.4 & 8.4 & 0.012 \\
\hline 13 & 62.0 & 10.3 & 1.4 & 2.8 & 4.3 & $>100$ & 0.62 & 4.9 & 9.1 & 0.006 \\
\hline 14 & 51.0 & 12.1 & 1.2 & 11.3 & 1.5 & $>100$ & 0.81 & 30.8 & 12.6 & 0.027 \\
\hline 15 & 11.5 & 52.2 & 8.7 & 9.1 & 0.70 & $>100$ & 4.9 & 25.6 & 8.3 & 0.016 \\
\hline 16 & 18.7 & 43.3 & 0.18 & 48.7 & 1.6 & 46.3 & 0.23 & $>100$ & 9.5 & 0.94 \\
\hline 17 & 40.0 & 45.9 & 1.0 & 17.2 & 5.2 & $>100$ & 0.012 & $>100$ & 12.0 & 0.004 \\
\hline 18 & 13.8 & 50.3 & 0.24 & 14.1 & 43.1 & 51.8 & 0.009 & 43.8 & 11.8 & 0.073 \\
\hline 19 & 18.5 & 52.0 & 12.8 & 17.4 & 9.6 & $>100$ & 0.94 & $>100$ & 14.5 & 0.002 \\
\hline
\end{tabular}

Table 3 collected the activation profiles of five $\alpha$-CA isoforms belonging to two corals (STPCA, CruCA4), three bacteria (VchCA $\alpha$, SspCA, SazCA) and one protozoan (TcCA), which all showed very different sensitivity to this panel of amino acids and amines. The comparison of the biological in vitro data of coral CAs STPCA (Stylophora pystillata) and CruCA4 (Corallium rubrum) provided the general higher sensitivity in the low nanomolar range of CruCA4 to CA activators, especially biogenic amines. Only D-DOPA 10 represented the most interesting STPCA activator $\left(\mathrm{K}_{\mathrm{A}}=0.18 \mu \mathrm{M}\right)$ within the series and with two orders of magnitude with respect to its enantiomer (9, L-DOPA, $\left.\mathrm{K}_{\mathrm{A}}=15 \mu \mathrm{M}\right)$.

Regarding bacterial $\alpha$-CAs, whereas $\mathrm{VchCA} \alpha$ (Vibrio cholerae) was poorly activated by this set of molecules, kinetic data referred to SazCA (Sulfurihydrogenibium azorense) and SspCA (Sulfurihydrogenibium yellowstonense) except for compound 4 (D-Phe, $\mathrm{K}_{\mathrm{A}}=5.1 \mu \mathrm{M}$ ) showed a potent activation down to $\mathrm{K}_{\mathrm{A}}=0.002 \mu \mathrm{M}$. L-Phe, D-His, L-Trp and D-Trp were endowed with the best values, thus providing useful insights into the possibility to boost this enzyme for industrial and technological biomimetic $\mathrm{CO}_{2}$ capture. Finally, TcCA from the pathogenic Tripanosoma cruzi was strongly activated by non-proteinogenic amino acids (9-11) and the morpholine derivative 19.

The $\beta$-CAs family was also largely explored. They are well-represented in the Fungi kingdom as reported in Table 4. Collectively, this set of nitrogen-containing compounds had a limited activating activity, except for the fungal isoform MreCA (Malassezia restricta). Nonproteinogenic amines and amine neurotransmitters were preferred to obtain nanomolar activation constants. If we consider other $\beta$-CAs from bacteria and protozoa (Table 5), BpsCA $\beta, \mathrm{VchCA} \beta$ (Vibrio cholerae), BsuCA (Brucella suis) and LdcCA (Leishmania donovani chagasi) were the most sensitive to these compounds. Synthetic amines (16-19) were shown to be potent activators of LdcCA isoform, thus representing useful and selective tools to 
better understand the role this enzyme has in the complex life cycle of Leishmania. FtuCA (Francisella tularensis) was the least affected $\beta-\mathrm{CA}\left(\mathrm{K}_{\mathrm{A}}>30.5 \mu \mathrm{M}\right)$ within the series.

Among $\gamma$-CAs included in Table 6, these selected amine derivatives and amino acids displayed a strong preference for VchCA $\gamma$ (Vibrio cholerae) and Bps $\gamma \mathrm{CA}$ (Burkholderia pseudomallei) with $\mathrm{K}_{\mathrm{A}}$ values in the low nanomolar range, albeit a general SAR cannot be depicted. More in detail, the $\gamma$-class in $V$. cholerae was the most sensitive to these CAAs with respect to the other two genetic families. The rest of $\gamma$-CAs were not significantly affected by these CAAs.

Table 6. In vitro activation data $\left(\mathrm{K}_{\mathrm{A}}\right)$ of the remaining CA families with amine derivatives and amino acids (1-19). Each value is the mean from three different determinations with errors in the range of $5-10 \%$.

\begin{tabular}{|c|c|c|c|c|c|c|c|c|c|c|}
\hline \multirow{3}{*}{ Compound } & \multicolumn{10}{|c|}{$\mathrm{K}_{\mathrm{A}}(\mu \mathrm{M})$} \\
\hline & \multicolumn{6}{|c|}{$\gamma$-CAs } & \multirow{2}{*}{$\begin{array}{c}\delta \text {-CAs } \\
\text { TweCA } \delta\end{array}$} & \multirow{2}{*}{$\begin{array}{c}\zeta \text {-CAs } \\
\text { Zn- } \\
\text { TweCA } \zeta\end{array}$} & \multirow{2}{*}{$\begin{array}{c}\eta \text {-CAs } \\
\text { PfaCA }\end{array}$} & \multirow{2}{*}{$\begin{array}{l}\text { t-CAs } \\
\text { BteCA }\end{array}$} \\
\hline & Zn-Cam & Co-Cam & VchCA $\gamma$ & Bps $\gamma$ CA & PhaCA & CpsCA & & & & \\
\hline 1 & 68.0 & $>100$ & 1.0 & 24.7 & 12.6 & 47.5 & 0.75 & 0.81 & 1.1 & 8.6 \\
\hline 2 & 46.0 & 73.0 & 14.2 & 0.086 & 9.4 & 35.9 & 4.9 & 7.2 & 2.2 & 6.2 \\
\hline 3 & 68.0 & 70.0 & 0.73 & 1.7 & 15.8 & $>100$ & 2.2 & 15.4 & 0.43 & 36.5 \\
\hline 4 & 42.0 & 24.0 & 0.24 & 0.13 & 3.2 & 15.4 & 1.2 & 9.6 & 0.75 & 9.4 \\
\hline 5 & 38.0 & 47.0 & 0.008 & 0.43 & 7.1 & 21.3 & 0.93 & 8.5 & 5.2 & 10.2 \\
\hline 6 & 33.0 & 68.0 & 0.40 & 0.052 & 13.9 & 36.8 & 0.69 & 1.8 & 8.5 & 6.1 \\
\hline 7 & 24.0 & 53.0 & 0.12 & 0.20 & 1.0 & 19.5 & 1.5 & 0.98 & 1.0 & 8.0 \\
\hline 8 & nd & nd & 0.10 & 32.8 & 7.4 & 18.4 & 0.051 & 0.62 & 8.6 & 7.3 \\
\hline 9 & 39.0 & 38.0 & 0.19 & 0.072 & 1.1 & 4.8 & 2.1 & 3.2 & 0.12 & 4.3 \\
\hline 10 & 37.0 & 41.0 & 0.13 & 0.98 & 0.72 & 11.2 & 6.2 & 2.9 & 0.39 & 11.7 \\
\hline 11 & 72.0 & 22.0 & 0.69 & 0.009 & 3.3 & 17.2 & 18.9 & 7.9 & 1.0 & 6.9 \\
\hline 12 & 63.0 & 9.2 & 0.31 & 0.12 & 6.5 & 20.6 & 1.3 & 1.3 & 9.9 & 6.0 \\
\hline 13 & 38.0 & 0.97 & 0.17 & 0.10 & 9.1 & 34.8 & 0.90 & 3.1 & 7.2 & 13.3 \\
\hline 14 & 54.0 & 18.4 & 0.45 & 0.014 & 8.7 & 32.1 & 0.51 & 10.1 & 10.0 & 8.7 \\
\hline 15 & 39.0 & 8.9 & 0.11 & 0.019 & 17.5 & 79.8 & 2.4 & 0.092 & 2.4 & 9.7 \\
\hline 16 & 11.4 & 8.7 & 0.14 & 2.4 & 2.4 & 21.5 & 5.3 & 0.88 & 3.7 & 24.1 \\
\hline 17 & 24.0 & 18.5 & 0.26 & 0.034 & 18.7 & 38.2 & 8.2 & 0.85 & 6.8 & 21.5 \\
\hline 18 & 10.1 & 16.1 & 0.071 & 0.018 & 15.1 & 33.0 & 4.4 & 0.12 & 0.71 & 3.9 \\
\hline 19 & 45.0 & 38.0 & 0.054 & 0.015 & 10.1 & 34.2 & 7.4 & 0.15 & 5.3 & 12.0 \\
\hline
\end{tabular}

nd: not determined.

The activation data for the other families $\left(\delta_{-}, \zeta_{-}\right.$, and $\left.\eta-C A s\right)$ underlined the differences in the tertiary structure of these isozymes leading to a moderate sensitivity to both amines and amino acids. A new entry in this field was the recently discovered ı-CA (Burkholderia territorii). Despite most of the CAAs showed rather flat activating efficacy with $\mathrm{K}_{\mathrm{A}}$ values ranging between 3.9 and $45.6 \mu \mathrm{M}$ (compounds 1-19 and 71-75), the results suggested that small structural changes (e.g., the stereogenic center) in the compounds can induce important modifications of their CA activating properties. Moreover, the activation profile of these bacterial ı-class was very different from those of human CA I and II.

Beyond the well-known CAAs 1-19 and 71-75, Stefanucci et al. [87] explored six newly synthesized tripeptides (76-81) as trifluoroacetic acid salts of general formula $\mathrm{NH}_{2}-\mathrm{Xaa}_{1}-$ $\mathrm{Xaa}_{2}-\mathrm{Xaa}_{3}-\mathrm{NH}_{2}$ (Table 7 , being the amino acids of $\mathrm{L}$ series). First of all, they were totally inactive against human CA I and II $\left(\mathrm{K}_{\mathrm{A}}>50 \mu \mathrm{M}\right)$, whereas they displayed an interesting 
activation profile toward CAs from $V$. cholerae (VchCA $\beta$ and $V \operatorname{chCA} \gamma), \operatorname{mtCA} 3$ from $M$. tuberculosis and BpsCA $\gamma$ (from B. pseudomallei).

Table 7. In vitro activation data of selected CA families with six newly synthesized tripeptides (76-81). Each value is the mean from three different determinations with errors in the range of $5-10 \%$.

\begin{tabular}{|c|c|c|c|c|c|c|c|}
\hline \multirow{2}{*}{ Compound } & \multicolumn{3}{|c|}{$\mathrm{NH}_{2}-\mathrm{Xaa}_{1}-\mathrm{Xaa}_{2}-\mathrm{Xaa}_{3}-\mathrm{NH}_{2}$} & \multicolumn{4}{|c|}{$\mathrm{K}_{\mathrm{A}}(\mu \mathrm{M})$} \\
\hline & $\mathrm{Xaa}_{1}$ & $\mathrm{Xaa}_{2}$ & $\mathrm{Xaa}_{3}$ & $\mathrm{VchCA} \beta$ & mtCA3 & VchCA $\gamma$ & BpsCA $\gamma$ \\
\hline 76 & Tyr & Phe & Asp & 3.5 & 8.4 & 14.7 & 10.1 \\
\hline 77 & His & Phe & Glu & 1.2 & 6.3 & 5.8 & 1.6 \\
\hline 78 & Glu & Ile & Thr & 1.1 & 4.3 & 11.9 & 3.7 \\
\hline 79 & Gln & Asp & Ser & 0.21 & 15.8 & 12.9 & 6.2 \\
\hline 80 & Asn & Asp & Ser & 7.2 & 18.1 & 10.6 & 0.95 \\
\hline 81 & Glu & Phe & Glu & 4.2 & 9.4 & 2.7 & 5.2 \\
\hline
\end{tabular}

VchCA $\beta$ and $\operatorname{BpsCA} \gamma$ were efficiently activated by these tripeptides in the range 0.21-10.1 $\mu \mathrm{M}$. The most promising derivatives shared a common skeleton at position $\mathrm{Xaa}_{2}$ (Asp) and $\mathrm{Xaa}_{3}$ (Ser). The other two CA isoforms (mtCA3 and VchCA $\gamma$ ) were less affected by these compounds, which displayed a better preference for $V$. cholerae CA isoforms.

CAAs for these isozymes can be useful for two main reasons. Firstly, taking into account the paramount role in coral reef ecosystems of organisms using CAs in symbiosis or calcification processes, the activation of these isoforms can improve or sustain photosynthesis and biomineralization. These two aspects have gained attention to the emerging concern due to the harmful ocean acidification, climate changes and marine pollution and led the scientists to better understand physiological pathways towards carbon-concentrating mechanisms and how to improve them [107]. Secondly, in a larger effort for green $\mathrm{CO}_{2}$-capture, -utilization and -storage, microbial $\mathrm{CAs}$ have been engineered to develop more efficient technologies for an improved mineral carbonation. Moreover, this result can be also achieved by the use of activators avoiding low stability under industrial conditions [110].

\section{Conclusions}

The field of carbonic anhydrase activators has been underexplored so far due to the skepticism that scientists experienced regarding an enzyme which usually improves the rate of an important biological reaction. However, after the preliminary demonstration of this phenomenon with a handful of different available hCA-activator X-ray structures, activators were seen not only as tools to unravel the enzymatic mechanism (favoring the proton shuttling), but also as therapeutic and industrial agents. Indeed, CA-deficiency syndromes for many human isoforms (CA I, II, IV, VA, XII and XIV) and the tissue engineering field make these activators rather promising, especially in the memory therapy and to obtain artificial bone fragments, respectively. This approach has been corroborated by in vivo studies of enhancement of spatial memory and learning [66].

Beyond anions and sulfonamides as inhibitors, amino acids and amine derivatives were the most explored compounds and scaffolds to generate rather potent and selective CAAs among the 13 mammalian isoforms and the others belonging to different living organisms. Most of the compounds were derived from proteinogenic and non-proteinogenic amino acids, and neurotransmitters, by the introduction of moieties characterized by specific $\mathrm{pK}_{\mathrm{a}}$ values and lipophilicity. All the compounds reported in this review were published performing the same procedure and using the same instrument, thus ensuring a strong reproducibility of the data and robust SARs. Further significant developments are expected from this less explored field in medicinal chemistry, especially regarding the $\theta$-CA family and the availability of X-rays analysis of CA-activator complexes with not human isozymes. 
Author Contributions: Conceptualization, C.T.S. and G.C.; methodology, S.C., E.B., F.C.; writing and draft preparation, A.A., S.C., E.B., F.C. and M.C. All authors have read and agreed to the published version of the manuscript.

Funding: This research was supported by the Italian Ministry for University and Research (MIUR) [grant number FISR2019_04819 BacCAD to S.C., G.C. and C.T.S.] and the Italian Ministry for University and Research (MIUR) [grant PRIN: rot. 2017XYBP2R to G.C. and C.T.S.]

Data Availability Statement: Data are contained within the article.

Conflicts of Interest: The authors declare no conflict of interest.

\section{References}

1. Blaskovich, M.A.T. Unusual Amino Acids in Medicinal Chemistry. J. Med. Chem. 2016, 59, 10807-10836. [CrossRef] [PubMed]

2. Akgül, Ö.; Angeli, A.; Vullo, D.; Carta, F.; Supuran, C.T. Unconventional Amino Acids in Medicinal Chemistry: First Report on Taurine Merged within Carbonic Anhydrase Inhibitors. Bioorg. Chem. 2020, 103, 104236. [CrossRef] [PubMed]

3. Akocak, S.; Supuran, C.T. Activation of $\alpha-, \beta-, \gamma-\delta-, \zeta-$ and $\eta$-Class of Carbonic Anhydrases with Amines and Amino Acids: A Review. J. Enzym. Inhib. Med. Chem. 2019, 34, 1652-1659. [CrossRef]

4. Bunch, L.; Krogsgaard-Larsen, P. Medicinal Chemistry of $\alpha$-Amino Acids. In Amino Acids, Peptides and Proteins in Organic Chemistry; Wiley-VCH Verlag GmbH \& Co. KGaA: Weinheim, Germany, 2011; Volume 4, pp. 149-174.

5. Nuñez, M.; del Olmo, A.; Calzada, J. Biogenic Amines. In Encyclopedia of Food and Health; Elsevier: Amsterdam, The Netherlands, 2015; pp. 416-423. ISBN 9780123849533.

6. Supuran, C.T. Carbonic Anhydrases: Novel Therapeutic Applications for Inhibitors and Activators. Nat. Rev. Drug Discov. 2008, 7, 168-181. [CrossRef] [PubMed]

7. Nocentini, A.; Supuran, C.T.; Capasso, C. An Overview on the Recently Discovered Iota-Carbonic Anhydrases. J. Enzym. Inhib. Med. Chem. 2021, 36, 1988-1995. [CrossRef] [PubMed]

8. Alterio, V.; Di Fiore, A.; D'Ambrosio, K.; Supuran, C.T.; De Simone, G. Multiple Binding Modes of Inhibitors to Carbonic Anhydrases: How to Design Specific Drugs Targeting 15 Different Isoforms? Chem. Rev. 2012, 112, 4421-4468. [CrossRef]

9. Flaherty, D.P.; Seleem, M.N.; Supuran, C.T. Bacterial Carbonic Anhydrases: Underexploited Antibacterial Therapeutic Targets. Future Med. Chem. 2021, 13, 1619-1622. [CrossRef] [PubMed]

10. Boone, C.D.; Pinard, M.; McKenna, R.; Silverman, D. Catalytic Mechanism of $\alpha$-Class Carbonic Anhydrases: $\mathrm{CO}_{2} \mathrm{Hydration}$ and Proton Transfer. Subcell. Biochem. 2014, 75, 31-52.

11. Murray, A.B.; McKenna, R. $\beta$-Carbonic anhydrases. In Carbonic Anhydrases: Biochemistry and Pharmacology of an Evergreen Pharmaceutical Target; Elsevier: Amsterdam, The Netherlands, 2019; pp. 55-77. ISBN 9780128164761.

12. Tripp, B.C.; Ferry, J.G. A Structure-Function Study of a Proton Transport Pathway in the $\gamma$-Class Carbonic Anhydrase from Methanosarcina Thermophila. Biochemistry 2000, 39, 9232-9240. [CrossRef] [PubMed]

13. Kisker, C.; Schindelin, H.; Alber, B.E.; Ferry, J.G.; Rees, D.C. A Left-Hand Beta-Helix Revealed by the Crystal Structure of a Carbonic Anhydrase from the Archaeon Methanosarcina Thermophila. EMBO J. 1996, 15, 2323. [CrossRef] [PubMed]

14. Alber, B.E.; Colangelo, C.M.; Dong, J.; Stålhandske, C.M.V.; Baird, T.T.; Tu, C.; Fierke, C.A.; Silverman, D.N.; Robert, A.; Scott, A.; et al. Kinetic and Spectroscopic Characterization of the Gamma-Carbonic Anhydrase from the Methanoarchaeon Methanosarcina Thermophila. Biochemistry 1999, 38, 13119-13128. [CrossRef] [PubMed]

15. Capasso, C. $\delta$-Carbonic anhydrases. In Carbonic Anhydrases: Biochemistry and Pharmacology of an Evergreen Pharmaceutical Target; Academic Press: Cambridge, MA, USA, 2019; pp. 107-129.

16. Lane, T.W.; Saito, M.A.; George, G.N.; Pickering, I.J.; Prince, R.C.; Morel, F.M. Biochemistry: A Cadmium Enzyme from a Marine Diatom. Nature 2005, 435, 42. [CrossRef]

17. McGinn, P.J.; Morel, F.M. Expression and Regulation of Carbonic Anhydrases in the Marine Diatom Thalassiosira pseudonana and in Natural Phytoplankton Assemblages from Great Bay, New Jersey. Physiol. Plant. 2008, 133, 78-91. [CrossRef] [PubMed]

18. Xu, Y.; Feng, L.; Jeffrey, P.D.; Shi, Y.; Morel, F.M. Structure and Metal Exchange in the Cadmium Carbonic Anhydrase of Marine Diatoms. Nature 2008, 452, 56-61. [CrossRef] [PubMed]

19. Angeli, A.; Buonanno, M.; Donald, W.A.; Monti, S.M.; Supuran, C.T. The Zinc-But Not Cadmium-Containing $\zeta-C a r b o n i c$ from the Diatom Thalassiosira Weissflogii Is Potently Activated by Amines and Amino Acids. Bioorg. Chem. 2018, 80, 261-265. [CrossRef] [PubMed]

20. Krungkrai, J.; Prapunwatana, P.; Wichitkul, C.; Reungprapavut, S.; Krungkrai, S.R.; Horii, T. Molecular Biology and Biochemistry of Malarial Parasite Pyrimidine Biosynthetic Pathway-PubMed. Southeast. Asian J. Trop. Med. Public Health 2003, $34,32-43$. [PubMed]

21. Krungkrai, S.R.; Suraveratum, N.; Rochanakij, S.; Krungkrai, J. Characterisation of Carbonic Anhydrase in Plasmodium Falciparum. Int. J. Parasitol. 2001, 31, 661-668. [CrossRef]

22. Del Prete, S.; Vullo, D.; De Luca, V.; Carginale, V.; Osman, S.M.; AlOthman, Z.; Supuran, C.T.; Capasso, C. Cloning, Expression, Purification and Sulfonamide Inhibition Profile of the Complete Domain of the $\eta$-Carbonic Anhydrase from Plasmodium Falciparum. Bioorg. Med. Chem. Lett. 2016, 26, 4184-4190. [CrossRef] [PubMed] 
23. Del Prete, S.; De Luca, V.; De Simone, G.; Supuran, C.T.; Capasso, C. Cloning, Expression and Purification of the Complete Domain of the $\eta$-Carbonic Anhydrase from Plasmodium Falciparum. J. Enzyme Inhib. Med. Chem. 2016, 31, 54-59. [CrossRef]

24. Hou, W.-C.; Chen, H.-J.; Yaw-Huei, L. Dioscorins from Different Dioscorea Species All Exhibit Both Carbonic Anhydrase and Trypsin Inhibitor Activities. Bot. Bull. Acad. Sin. 2000, 41, 191-196.

25. Kikutani, S.; Nakajima, K.; Nagasato, C.; Tsuji, Y.; Miyatake, A.; Matsuda, Y. Thylakoid Luminal $\theta$-Carbonic Anhydrase Critical for Growth and Photosynthesis in the Marine Diatom Phaeodactylum Tricornutum. Proc. Natl. Acad. Sci. USA 2016, 113, $9828-9833$. [CrossRef]

26. Jensen, E.L.; Clement, R.; Kosta, A.; Maberly, S.C.; Gontero, B. A New Widespread Subclass of Carbonic Anhydrase in Marine Phytoplankton. ISME J. 2019, 13, 2094-2106. [CrossRef]

27. Del Prete, S.; Nocentini, A.; Supuran, C.T.; Capasso, C. Bacterial ı-Carbonic Anhydrase: A New Active Class of Carbonic Anhydrase Identified in the Genome of the Gram-Negative Bacterium Burkholderia Territorii. J. Enzyme Inhib. Med. Chem. 2020, 35, 1060-1068. [CrossRef] [PubMed]

28. Jensen, E.L.; Receveur-Brechot, V.; Hachemane, M.; Wils, L.; Barbier, P.; Parsiegla, G.; Gontero, B.; Launay, H.; Magyar, C. Structural Contour Map of the Iota Carbonic Anhydrase from the Diatom Thalassiosira Pseudonana Using a Multiprong Approach. Int. J. Mol. Sci. 2021, 22, 8723. [CrossRef] [PubMed]

29. Hirakawa, Y.; Senda, M.; Fukuda, K.; Yang Yu, H.; Ishida, M.; Taira, M.; Kinbara, K.; Senda, T. Characterization of a Novel Type of Carbonic Anhydrase That Acts without Metal Cofactors. BMC Biol. 2021, 19, 105. [CrossRef] [PubMed]

30. Leiner, M. Das Ferment Kohlensäureanhydrase Im Tierkörper. Naturwissenschaften 1940, 28, 316-317. [CrossRef]

31. Leiner, M.; Leiner, G. Die Aktivatoren Der Kohlensäureanhydratase. Naturwissenschaften 1941, 29, 195-197. [CrossRef]

32. Kiese, M. Die Aktivierung Der Kohlensäureanhydrase. Naturwissenschaften 1941, 29, 116-117. [CrossRef]

33. Edna Main, B.R.; Locke, A. Carbonic Anhydrase, I. Factors Affecting Activity. J. Biol. Chem. 1941, 140, 909-918.

34. Supuran, C.T. Carbonic Anhydrase Activators. Part 4. A General Mechanism of Action for Activators of Isozyme-I, Isozyme-II and Isozyme-III. Rev. Roum. Chim. 1992, 37, 411-421.

35. Supuran, C.T.; Balaban, A.T. Carbonic Anhydrase Activators. Part 8. PKa-Activation Relationship in a Series of Amino Acid Derivatives Activators of Isozyme II. Rev. Roum. Chim. 1994, 39, 107-113.

36. Tu, C.; Silverman, D.N.; Forsman, C.; Jonsson, B.H.; Lindskog, S. Role of Histidine 64 in the Catalytic Mechanism of Human Carbonic Anhydrase II Studied with a Site-Specific Mutant. Biochemistry 1989, 28, 7913-7918. [CrossRef]

37. Briganti, F.; Mangani, S.; Orioli, P.; Scozzafava, A.; Vernaglione, G.; Supuran, C.T. Carbonic Anhydrase Activators: X-Ray Crystallographic and Spectroscopic Investigations for the Interaction of Isozymes I and II with Histamine. Biochemistry 1997, 36, 10384-10392. [CrossRef]

38. Supuran, C.T. Carbonic Anhydrase Activators. Future Med. Chem. 2018, 10, 561-573. [CrossRef] [PubMed]

39. Temperini, C.; Scozzafava, A.; Vullo, D.; Supuran, C.T. Carbonic Anhydrase Activators. Activation of Isozymes I, II, IV, VA, VII, and XIV with L- and D-Histidine and Crystallographic Analysis of Their Adducts with Isoform II: Engineering Proton-Transfer Processes within the Active Site of an Enzyme. Chem. A Eur. J. 2006, 12, 7057-7066. [CrossRef] [PubMed]

40. Temperini, C.; Scozzafava, A.; Vullo, D.; Supuran, C.T. Carbonic Anhydrase Activators, Activation of Isoforms I, II, IV, VA, VII, and XIV with L- and D-Phenylalanine and Crystallographic Analysis of Their Adducts with Isozyme II: Stereospecific Recognition within the Active Site of an Enzyme and Its Consequenc. J. Med. Chem. 2006, 49, 3019-3027. [CrossRef] [PubMed]

41. Temperini, C.; Innocenti, A.; Scozzafava, A.; Mastrolorenzo, A.; Supuran, C.T. Carbonic Anhydrase Activators: L-Adrenaline Plugs the Active Site Entrance of Isozyme II, Activating Better Isoforms I, IV, VA, VII, and XIV. Bioorg. Med. Chem. Lett. 2007, 17, 628-635. [CrossRef]

42. Temperini, C.; Innocenti, A.; Scozzafava, A.; Supuran, C.T. Carbonic Anhydrase Activators: Kinetic and X-Ray Crystallographic Study for the Interaction of d- and 1-Tryptophan with the Mammalian Isoforms I-XIV. Bioorg. Med. Chem. 2008, 16, 8373-8378. [CrossRef] [PubMed]

43. Petreni, A.; Osman, S.M.; Alasmary, F.A.; Almutairi, T.M.; Nocentini, A.; Supuran, C.T. Binding Site Comparison for Coumarin Inhibitors and Amine/Amino Acid Activators of Human Carbonic Anhydrases. Eur. J. Med. Chem. 2021, 226, 113875. [CrossRef]

44. Supuran, C.T. Coumarin Carbonic Anhydrase Inhibitors from Natural Sources. J. Enzym. Inhib. Med. Chem. 2020, 35, 1462-1470. [CrossRef]

45. Maresca, A.; Temperini, C.; Pochet, L.; Masereel, B.; Scozzafava, A.; Supuran, C.T. Deciphering the Mechanism of Carbonic Anhydrase Inhibition with Coumarins and Thiocoumarins. J. Med. Chem. 2010, 53, 335-344. [CrossRef]

46. Angeli, A.; Carta, F.; Nocentini, A.; Winum, J.Y.; Zalubovskis, R.; Onnis, V.; Eldehna, W.M.; Capasso, C.; Carradori, S.; Donald, W.A.; et al. Response to Perspectives on the Classical Enzyme Carbonic Anhydrase and the Search for Inhibitors. Biophys. J. 2021, 120, 178-181. [CrossRef] [PubMed]

47. Khalifa, R. The Carbon Dioxide Hydration Activity of Carbonic Anhydrase. I. Stop-Flow Kinetic Studies on the Native Human Isoenzymes B and C. J. Biol. Chem. 1971, 246, 2561-2573. [CrossRef]

48. Angeli, A.; Vaiano, F.; Mari, F.; Bertol, E.; Supuran, C.T. Psychoactive Substances Belonging to the Amphetamine Class Potently Activate Brain Carbonic Anhydrase Isoforms VA, VB, VII, and XII. J. Enzym. Inhib. Med. Chem. 2017, 32, 1253-1259. [CrossRef] [PubMed] 
49. Scozzafava, A.; Iorga, B.; Supuran, C.T. Carbonic Anhydrase Activators: Synthesis of High Affinity Isozymes I, II and IV Activators, Derivatives of 4-(4-Tosylureido-Amino Acyl)Ethyl-1H-Imidazole (Histamine Derivatives). J. Enzym. Inhib. 2000, 15, 139-161. [CrossRef] [PubMed]

50. Briganti, F.; Scozzafava, A.; Supuran, C.T. Novel Carbonic Anhydrase Isozymes I, II and IV Activators Incorporating SulfonylHistamino Moieties. Bioorg. Med. Chem. Lett. 1999, 9, 2043-2048. [CrossRef]

51. Supuran, C.T.; Scozzafava, A. Carbonic Anhydrase Activators: Amino Acyl/Dipeptidyl Histamine Derivatives Bind with High Affinity to Isozymes I, II and IV and Act as Efficient Activators. Bioorg. Med. Chem. 1999, 7, 2915-2923. [CrossRef]

52. Scozzafava, A.; Supuran, C.T. Carbonic Anhydrase Activators: Part 24. High Affinity Isozymes I, II and IV Activators, Derivatives of 4-(4-Chlorophenylsulfonylureido-Amino Acyl)Ethyl-1H-Imidazole. Eur. J. Pharm. Sci. 2000, 10, 29-41. [CrossRef]

53. Scozzafava, A.; Supuran, C.T. Carbonic Anhydrase Activators-Part 21. Novel Activators of Isozymes I, II and IV Incorporating Carboxamido and Ureido Histamine Moieties. Eur. J. Med. Chem. 2000, 35, 31-39. [CrossRef]

54. Akocak, S.; Lolak, N.; Vullo, D.; Durgun, M.; Supuran, C.T. Synthesis and Biological Evaluation of Histamine Schiff Bases as Carbonic Anhydrase I, II, IV, VII, and IX Activators. J. Enzym. Inhib. Med. Chem. 2017, 32, 1305-1312. [CrossRef]

55. Dave, K.; Ilies, M.A.; Scozzafava, A.; Temperini, C.; Vullo, D.; Supuran, C.T. An Inhibitor-like Binding Mode of a Carbonic Anhydrase Activator within the Active Site of Isoform II. Bioorg. Med. Chem. Lett. 2011, 21, 2764-2768. [CrossRef] [PubMed]

56. Saada, M.C.; Montero, J.L.; Vullo, D.; Scozzafava, A.; Winum, J.Y.; Supuran, C.T. Carbonic Anhydrase Activators: Gold Nanoparticles Coated with Derivatized Histamine, Histidine, and Carnosine Show Enhanced Activatory Effects on Several Mammalian Isoforms. J. Med. Chem. 2011, 54, 1170-1177. [CrossRef] [PubMed]

57. Supuran, C.T.; Barboiu, M.; Luca, C.; Pop, E.; Brewster, M.E.; Dinculescu, A. Carbonic Anhydrase Activators. Part 14. Syntheses of Mono and Bis Pyridinium Salt Derivatives of 2-Amino-5-(2-Aminoethyl)- and 2-Amino-5-(3-Aminopropyl)-1,3,4-Thiadiazole and Their Interaction with Isozyme II. Eur. J. Med. Chem. 1996, 31, 597-606. [CrossRef]

58. Rami, M.; Winum, J.-Y.; Supuran, C.T.; Melnyk, P.; Yous, S. (Hetero)Aryl Substituted Thiazol-2,4-Yl Scaffold as Human Carbonic Anhydrase I, II, VII and XIV Activators. J. Enzym. Inhib. Med. Chem. 2019, 34, 224. [CrossRef] [PubMed]

59. Saada, M.C.; Vullo, D.; Montero, J.L.; Scozzafava, A.; Winum, J.Y.; Supuran, C.T. Carbonic Anhydrase I and II Activation with Mono- and Dihalogenated Histamine Derivatives. Bioorg. Med. Chem. Lett. 2011, 21, 4884-4887. [CrossRef]

60. Draghici, B.; Vullo, D.; Akocak, S.; Walker, E.A.; Supuran, C.T.; Ilies, M.A. Ethylene Bis-Imidazoles Are Highly Potent and Selective Activators for Isozymes VA and VII of Carbonic Anhydrase, with a Potential Nootropic Effect. Chem. Commun. 2014, 50, 5980-5983. [CrossRef]

61. Aggarwal, M.; Kondeti, B.; Tu, C.; Maupin, C.M.; Silverman, D.N.; McKenna, R. Structural Insight into Activity Enhancement and Inhibition of H64A Carbonic Anhydrase II by Imidazoles. IUCrJ 2014, 1, 129. [CrossRef]

62. Akocak, S.; Lolak, N.; Bua, S.; Nocentini, A.; Supuran, C.T. Activation of Human $\alpha$-Carbonic Anhydrase Isoforms I, II, IV and VII with Bis-Histamine Schiff Bases and Bis-Spinaceamine Substituted Derivatives. J. Enzym. Inhib. Med. Chem. 2019, 34, 1193-1198. [CrossRef]

63. Akocak, S.; Lolak, N.; Bua, S.; Nocentini, A.; Karakoc, G.; Supuran, C.T. $\alpha$-Carbonic Anhydrases Are Strongly Activated by Spinaceamine Derivatives. Bioorg. Med. Chem. 2019, 27, 800-804. [CrossRef]

64. Ghiasi, M.; Shahabi, P.; Supuran, C.T. Quantum Mechanical Study on the Activation Mechanism of Human Carbonic Anhydrase VII Cluster Model with Bis-Histamine Schiff Bases and Bis-Spinaceamine Derivatives. Bioorg. Med. Chem. 2021, $44,116276$. [CrossRef]

65. Mollica, A.; Macedonio, G.; Stefanucci, A.; Carradori, S.; Akdemir, A.; Angeli, A.; Supuran, C. Five- and Six-Membered Nitrogen-Containing Compounds as Selective Carbonic Anhydrase Activators. Molecules 2017, 22, 2178. [CrossRef] [PubMed]

66. Provensi, G.; Nocentini, A.; Passani, M.B.; Blandina, P.; Supuran, C.T. Activation of Carbonic Anhydrase Isoforms Involved in Modulation of Emotional Memory and Cognitive Disorders with Histamine Agonists, Antagonists and Derivatives. J. Enzym. Inhib. Med. Chem. 2021, 36, 719-726. [CrossRef]

67. Scozzafava, A.; Supuran, C.T. Carbonic Anhydrase Activators: High Affinity Isozymes I, II, and IV Activators, Incorporating a $\beta$-Alanyl-Histidine Scaffold. J. Med. Chem. 2002, 45, 284-291. [CrossRef] [PubMed]

68. Abdo, M.R.; Vullo, D.; Saada, M.C.; Montero, J.L.; Scozzafava, A.; Winum, J.Y.; Supuran, C.T. Carbonic Anhydrase Activators: Activation of Human Isozymes I, II and IX with Phenylsulfonylhydrazido l-Histidine Derivatives. Bioorg. Med. Chem. Lett. 2009, 19, 2440-2443. [CrossRef]

69. Saada, M.C.; Vullo, D.; Montero, J.L.; Scozzafava, A.; Supuran, C.T.; Winum, J.Y. Mono- and Di-Halogenated Histamine, Histidine and Carnosine Derivatives Are Potent Carbonic Anhydrase I, II, VII, XII and XIV Activators. Bioorg. Med. Chem. 2014, 22, 4752-4758. [CrossRef] [PubMed]

70. Vistoli, G.; Aldini, G.; Fumagalli, L.; Dallanoce, C.; Angeli, A.; Supuran, C.T. Activation Effects of Carnosine- and HistidineContaining Dipeptides on Human Carbonic Anhydrases: A Comprehensive Study. Int. J. Mol. Sci. 2020, 21, 1761-1771. [CrossRef]

71. Tanini, D.; Capperucci, A.; Supuran, C.T.; Angeli, A. Sulfur, Selenium and Tellurium Containing Amines Act as Effective Carbonic Anhydrase Activators. Bioorg. Chem. 2019, 87, 516-522. [CrossRef] [PubMed]

72. Nocentini, A.; Cuffaro, D.; Ciccone, L.; Orlandini, E.; Nencetti, S.; Nuti, E.; Rossello, A.; Supuran, C.T. Activation of Carbonic Anhydrases from Human Brain by Amino Alcohol Oxime Ethers: Towards Human Carbonic Anhydrase VII Selective Activators. J. Enzym. Inhib. Med. Chem. 2020, 36, 48-57. [CrossRef] [PubMed] 
73. Sugimoto, A.; Ikeda, H.; Tsukamoto, H.; Kihira, K.; Ishioka, M.; Hirose, J.; Hata, T.; Fujioka, H.; Ono, Y. Timolol Activates the Enzyme Activities of Human Carbonic Anhydrase I and II. Biol. Pharm. Bull. 2010, 33, 301-306. [CrossRef] [PubMed]

74. Maccallini, C.; Di Matteo, M.; Vullo, D.; Ammazzalorso, A.; Carradori, S.; De Filippis, B.; Fantacuzzi, M.; Giampietro, L.; Pandolfi, A.; Supuran, C.T.; et al. Indazole, Pyrazole, and Oxazole Derivatives Targeting Nitric Oxide Synthases and Carbonic Anhydrases. ChemMedChem 2016, 11, 1695-1699. [CrossRef] [PubMed]

75. Sun, M.-K.; Alkon, D.L. Pharmacological Enhancement of Synaptic Efficacy, Spatial Learning, and Memory through Carbonic Anhydrase Activation in Rats. J. Pharmacol. Exp. Ther. 2001, 297.

76. Sun, M.K.; Alkon, D.L. Carbonic Anhydrase Gating of Attention: Memory Therapy and Enhancement. Trends Pharmacol. Sci. 2002, 23, 83-89. [CrossRef]

77. Meier-Ruge, W.; Iwangoff, P.; Reichlmeier, K. Neurochemical Enzyme Changes in Alzheimer's and Pick's Disease. Arch. Gerontol. Geriatr. 1984, 3, 161-165. [CrossRef]

78. Canto de Souza, L.; Provensi, G.; Vullo, D.; Carta, F.; Scozzafava, A.; Costa, A.; Schmidt, S.D.; Passani, M.B.; Supuran, C.T.; Blandina, P. Carbonic Anhydrase Activation Enhances Object Recognition Memory in Mice through Phosphorylation of the Extracellular Signal-Regulated Kinase in the Cortex and the Hippocampus. Neuropharmacology 2017, 118, 148-156. [CrossRef] [PubMed]

79. Schmidt, S.D.; Costa, A.; Rani, B.; Nachtigall, E.G.; Passani, M.B.; Carta, F.; Nocentini, A.; De Carvalho Myskiw, J.; Furini, C.R.G.; Supuran, C.T.; et al. The Role of Carbonic Anhydrases in Extinction of Contextual Fear Memory. Proc. Natl. Acad. Sci. USA 2020, 117, 16000-16008. [CrossRef]

80. Blandina, P.; Provensi, G.; Passsani, M.B.; Capasso, C.; Supuran, C.T. Carbonic Anhydrase Modulation of Emotional Memory. Implications for the Treatment of Cognitive Disorders. J. Enzym. Inhib. Med. Chem. 2020, 35, 1206-1214. [CrossRef] [PubMed]

81. Giovannini, M.G.; Efoudebe, M.; Passani, M.B.; Baldi, E.; Bucherelli, C.; Giachi, F.; Corradetti, R.; Blandina, P. Improvement in Fear Memory by Histamine-Elicited ERK2 Activation in Hippocampal CA3 Cells. J. Neurosci. 2003, 23, 9016-9023. [CrossRef]

82. Wang, X.; Schröder, H.C.; Schlossmacher, U.; Neufurth, M.; Feng, Q.; Diehl-Seifert, B.; Müller, W.E.G. Modulation of the Initial Mineralization Process of SaOS-2 Cells by Carbonic Anhydrase Activators and Polyphosphate. Calcif. Tissue Int. 2014, 94, 495-509. [CrossRef]

83. Müller, W.E.G.; Schröder, H.C.; Schlossmacher, U.; Grebenjuk, V.A.; Ushijima, H.; Wang, X. Induction of Carbonic Anhydrase in SaOS-2 Cells, Exposed to Bicarbonate and Consequences for Calcium Phosphate Crystal Formation. Biomaterials 2013, 34, 8671-8680. [CrossRef]

84. Vullo, D.; De Luca, V.; Scozzafava, A.; Carginale, V.; Rossi, M.; Supuran, C.T.; Capasso, C. The First Activation Study of a Bacterial Carbonic Anhydrase (CA). the Thermostable $\alpha$-CA from Sulfurihydrogenibium Yellowstonense YO3AOP1 Is Highly Activated by Amino Acids and Amines. Bioorg. Med. Chem. Lett. 2012, 22, 6324-6327. [CrossRef] [PubMed]

85. Angeli, A.; Del Prete, S.; Osman, S.M.; Alasmary, F.A.S.; AlOthman, Z.; Donald, W.A.; Capasso, C.; Supuran, C.T. Activation Studies of the $\alpha$-and $\beta$-Carbonic Anhydrases from the Pathogenic Bacterium Vibrio Cholerae with Amines and Amino Acids. J. Enzym. Inhib. Med. Chem. 2018, 33, 227-233. [CrossRef]

86. Angeli, A.; Del Prete, S.; Donald, W.A.; Capasso, C.; Supuran, C.T. The $\gamma$-Carbonic Anhydrase from the Pathogenic Bacterium Vibrio Cholerae Is Potently Activated by Amines and Amino Acids. Bioorg. Chem. 2018, 77, 1-5. [CrossRef] [PubMed]

87. Stefanucci, A.; Angeli, A.; Dimmito, M.P.; Luisi, G.; Del Prete, S.; Capasso, C.; Donald, W.A.; Mollica, A.; Supuran, C.T. Activation of $\beta$ - and $\gamma$-Carbonic Anhydrases from Pathogenic Bacteria with Tripeptides. J. Enzyme Inhib. Med. Chem. 2018, 33, 945-950. [CrossRef] [PubMed]

88. Angeli, A.; Del Prete, S.; Osman, S.M.; Alasmary, F.A.S.; AlOthman, Z.; Donald, W.A.; Capasso, C.; Supuran, C.T. Activation Studies with Amines and Amino Acids of the $\beta$-Carbonic Anhydrase Encoded by the Rv3273 Gene from the Pathogenic Bacterium Mycobacterium Tuberculosis. J. Enzym. Inhib. Med. Chem. 2018, 33, 364-369. [CrossRef] [PubMed]

89. Innocenti, A.; Zimmerman, S.A.; Scozzafava, A.; Ferry, J.G.; Supuran, C.T. Carbonic Anhydrase Activators: Activation of the Archaeal $\beta$-Class (Cab) and $\gamma$-Class (Cam) Carbonic Anhydrases with Amino Acids and Amines. Bioorg. Med. Chem. Lett. 2008, 18, 6194-6198. [CrossRef]

90. Nocentini, A.; Del Prete, S.; Mastrolorenzo, M.D.; Donald, W.A.; Capasso, C.; Supuran, C.T. Activation Studies of the $\beta$-Carbonic Anhydrases from Escherichia Coli with Amino Acids and Amines. J. Enzyme Inhib. Med. Chem. 2020, 35, 1379-1386. [CrossRef] [PubMed]

91. Angeli, A.; Del Prete, S.; Pinteala, M.; Maier, S.S.; Donald, W.A.; Simionescu, B.C.; Capasso, C.; Supuran, C.T. The First Activation Study of the $\beta$-Carbonic Anhydrases from the Pathogenic Bacteria Brucella Suis and Francisella Tularensis with Amines and Amino Acids. J. Enzym. Inhib. Med. Chem. 2019, 34, 1178-1185. [CrossRef] [PubMed]

92. Vullo, D.; Del Prete, S.; Osman, S.M.; AlOthman, Z.; Capasso, C.; Donald, W.A.; Supuran, C.T. Burkholderia Pseudomallei $\gamma$-Carbonic Anhydrase Is Strongly Activated by Amino Acids and Amines. Bioorg. Med. Chem. Lett. 2017, 27, 77-80. [CrossRef] [PubMed]

93. Angeli, A.; Del Prete, S.; Osman, S.M.; AlOthman, Z.; Donald, W.A.; Capasso, C.; Supuran, C.T. Activation Studies of the $\gamma$-Carbonic Anhydrases from the Antarctic Marine Bacteria Pseudoalteromonas Haloplanktis and Colwellia Psychrerythraea with Amino Acids and Amines. Mar. Drugs 2019, 17, 238. [CrossRef] [PubMed] 
94. De Luca, V.; Petreni, A.; Carginale, V.; Scaloni, A.; Supuran, C.T.; Capasso, C. Effect of Amino Acids and Amines on the Activity of the Recombinant ı-Carbonic Anhydrase from the Gram-Negative Bacterium Burkholderia territorii. J. Enzyme Inhib. Med. Chem. 2021, 36, 1000-1006. [CrossRef]

95. Isik, S.; Kockar, F.; Aydin, M.; Arslan, O.; Guler, O.O.; Innocenti, A.; Scozzafava, A.; Supuran, C.T. Carbonic Anhydrase Activators: Activation of the $\beta$-Carbonic Anhydrase Nce103 from the Yeast Saccharomyces Cerevisiae with Amines and Amino Acids. Bioorg. Med. Chem. Lett. 2009, 19, 1662-1665. [CrossRef] [PubMed]

96. Innocenti, A.; Hall, R.A.; Scozzafava, A.; Mühlschlegel, F.A.; Supuran, C.T. Carbonic Anhydrase Activators: Activation of the $\beta$-Carbonic Anhydrases from the Pathogenic Fungi Candida Albicans and Cryptococcus Neoformans with Amines and Amino Acids. Bioorg. Med. Chem. 2010, 18, 1034-1037. [CrossRef]

97. Innocenti, A.; Leewattanapasuk, W.; Manole, G.; Scozzafava, A.; Mühlschlegel, F.A.; Supuran, C.T. Carbonic Anhydrase Activators: Activation of the $\beta$-Carbonic Anhydrase from the Pathogenic Yeast Candida Glabrata with Amines and Amino Acids. Bioorg. Med. Chem. Lett. 2010, 20, 1701-1704. [CrossRef] [PubMed]

98. Vullo, D.; Del Prete, S.; Capasso, C.; Supuran, C.T. Carbonic Anhydrase Activators: Activation of the $\beta$-Carbonic Anhydrase from Malassezia Globosa with Amines and Amino Acids. Bioorg. Med. Chem. Lett. 2016, 26, 1381-1385. [CrossRef]

99. Angeli, A.; Prete, S. Del; Ghobril, C.; Hitce, J.; Clavaud, C.; Marrat, X.; Donald, W.A.; Capasso, C.; Supuran, C.T. Activation Studies of the $\beta$-Carbonic Anhydrases from Malassezia Restricta with Amines and Amino Acids. J. Enzyme Inhib. Med. Chem. 2020, 35, 824-830. [CrossRef] [PubMed]

100. Angeli, A.; Kuuslahti, M.; Parkkila, S.; Supuran, C.T. Activation Studies with Amines and Amino Acids of the $\alpha$-Carbonic Anhydrase from the Pathogenic Protozoan Trypanosoma Cruzi. Bioorg. Med. Chem. 2018, 26, 4187-4190. [CrossRef]

101. Angeli, A.; Donald, W.A.; Parkkila, S.; Supuran, C.T. Activation Studies with Amines and Amino Acids of the $\beta$-Carbonic Anhydrase from the Pathogenic Protozoan Leishmania Donovani Chagasi. Bioorg. Chem. 2018, 78, 406-410. [CrossRef] [PubMed]

102. Bua, S.; Haapanen, S.; Kuuslahti, M.; Parkkila, S.; Supuran, C.T. Activation Studies of the $\beta$-Carbonic Anhydrase from the Pathogenic Protozoan Entamoeba Histolytica with Amino Acids and Amines. Metabolites 2019, 9, 26. [CrossRef]

103. Angeli, A.; Urbański, L.J.; Hytönen, V.P.; Parkkila, S.; Supuran, C.T. Activation of the $\beta$-Carbonic Anhydrase from the Protozoan Pathogen Trichomonas Vaginalis with Amines and Amino Acids. J. Enzyme. Inhib. Med. Chem. 2021, 36, 758-763. [CrossRef]

104. Angeli, A.; Del Prete, S.; Alasmary, F.A.S.; Alqahtani, L.S.; AlOthman, Z.; Donald, W.A.; Capasso, C.; Supuran, C.T. The First Activation Studies of the $\eta$-Carbonic Anhydrase from the Malaria Parasite Plasmodium Falciparum with Amines and Amino Acids. Bioorg. Chem. 2018, 80, 94-98. [CrossRef]

105. Angeli, A.; Alasmary, F.A.S.; Del Prete, S.; Osman, S.M.; AlOthman, Z.; Donald, W.A.; Capasso, C.; Supuran, C.T. The First Activation Study of a $\delta$-Carbonic Anhydrase: TweCA $\delta$ from the Diatom Thalassiosira Weissflogii Is Effectively Activated by Amines and Amino Acids. J. Enzyme Inhib. Med. Chem. 2018, 33, 680-685. [CrossRef] [PubMed]

106. Del Prete, S.; Vullo, D.; Zoccola, D.; Tambutté, S.; Supuran, C.T.; Capasso, C. Activation Profile Analysis of CruCA4, an $\alpha$-Carbonic Anhydrase Involved in Skeleton Formation of the Mediterranean Red Coral, Corallium Rubrum. Molecules 2017, 23, 66. [CrossRef]

107. Bertucci, A.; Zoccola, D.; Tambutté, S.; Vullo, D.; Supuran, C.T. Carbonic Anhydrase Activators. The First Activation Study of a Coral Secretory Isoform with Amino Acids and Amines. Bioorg. Med. Chem. 2010, 18, 2300-2303. [CrossRef] [PubMed]

108. Su, D.; Zhang, Y.; Ulrich, S.; Barboiu, M. Constitutional Dynamic Inhibition/Activation of Carbonic Anhydrases. Chempluschem 2021, 86, 1500-1510. [CrossRef] [PubMed]

109. Alterio, V.; Langella, E.; Buonanno, M.; Esposito, D.; Nocentini, A.; Berrino, E.; Bua, S.; Polentarutti, M.; Supuran, C.T.; Monti, S.M.; et al. Zeta-Carbonic Anhydrases Show CS2 Hydrolase Activity: A New Metabolic Carbon Acquisition Pathway in Diatoms? Comput. Struct. Biotechnol. J. 2021, 19, 3427-3436. [CrossRef] [PubMed]

110. Bhagat, C.; Dudhagara, P.; Tank, S. Trends, application and future prospectives of microbial carbonic anhydrase mediated carbonation process for CCUS. J. Appl. Microbiol. 2018, 124, 316-335. [CrossRef] [PubMed] 